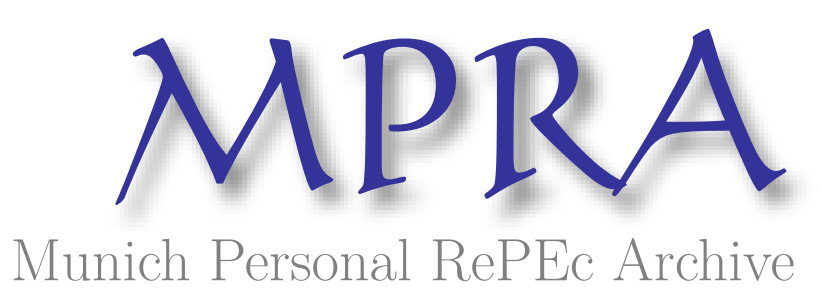

\title{
A Data Survey on International Capital Flows to Developing Countries
}

Keskinsoy, Bilal

Anadolu University

5 May 2017

Online at https://mpra.ub.uni-muenchen.de/78957/

MPRA Paper No. 78957, posted 06 May 2017 03:04 UTC 


\title{
A Data Survey on International Capital Flows to Developing Countries
}

\section{Bilal Keskinsoy}

Anadolu University

Department of Economics,

IIBF Building, Tepebaş1

26210 Eskişehir/TURKEY

bilalkeskinsoy@gmail.com

\begin{abstract}
This paper examines the data on international capital flows to developing economies for the period 1970-2006. Besides the most aggregate group of all developing countries, developing world is categorised with respect to five regions (Developing Asia, Europe and Central Asia, Latin America and Caribbean, Middle East and North Africa and Sub Saharan Africa) and three income groups (upper middle, lower middle and low). The overall structure and defining features of the data are discussed with reference to the main data sources, span of time and cross-section units and the core variables of interest. Trends and developments in aggregate capital flows, equity (FDI and portfolio) flows and debt (long-term and short-term) flows are assessed. Growth and cyclicality of these flows, FDI share of gross domestic investment, foreign participation in domestic stock markets and cost and maturity structure of external borrowing are analysed.
\end{abstract}

Keywords: Capital flows, Equity flows, Debt flows, Portfolio flows

JEL Codes: F21, F32, G15, O57 


\section{Introduction}

This paper examines the data on international capital flows to developing economies. The overall structure and defining features of the data are discussed with reference to the main data sources, span of time and cross-section units and the core variables of interest.

The Global Development Finance (GDF) database of the World Bank is the key source for the data series on capital movements. Although there is the word 'global' in its name, GDF covers only developing regions and countries including emerging and less developed. Being another and yet more extensive World Bank database, World Development Indicators (WDI) is used to get the indicators - mostly macroeconomic and financial sector-that are not available from the GDF. Databases such as International Financial Statistics (IFS), Balance of Payments Statistics (BOPS), World Economic Outlook (WEO) of the International Monetary Fund (IMF), United Nations Conference on Trade and Development (UNCTAD) and statistics portal of the Organisation for Economic Co-operation and Development (OECD) are also consulted for comparison and cross checks.

The years of observations range from 1970 to 2006, covering a maximum of 37 annual data points. This is the general case for the regions and income groups for which the data are available. The time length, particularly because of the changing initial years, varies considerably across countries and by different types of capital flow. As I look at the overall trends and developments in financial movements to developing markets in this paper, that should not be a concern at all. Country groups that are composed of developing countries from different income classes and geographical regions constitute the spatial domain. Although some data illustrations are based on the income groups for comparison purposes, the cross-section emphasis is on regions. The two Asian regions, East Asia and Pacific and South Asia, that are separately identified by the World Bank are combined under the name of Developing Asia (DA) as in WEO. Europe and Central Asia (ECA) comprises so-called transitional economies located in Eastern Europe and Central Asia as well as Turkey. ${ }^{1}$ The remaining regions, Latin America and Caribbean (LAC), Middle East and North Africa (MENA) and Sub-Saharan Africa (SSA) are the same as in Word Bank classifications. The chief grouping is All Developing Countries (ADC) for which the aggregate data consist of individual sums of regional data. Income groups are based on the World Bank's classification of countries according to the level of 2009 GNI per capita, calculated using the Atlas method:

\footnotetext{
${ }^{1}$ As a transition economy, Mongolia is classed with Central Asia.
} 
upper middle income countries (UMIC), which are also known as emerging markets, lower middle income countries (LMIC) and low income countries (LIC).

Despite the fact that all capital flow types serve similar economic goals through financing productive real investment opportunities, smoothing business and consumption cycles and offering diversification and risk sharing, there are differences in terms of functionality, type of the security, original contractual maturity, direction of the investment, and other contractual arrangements. For this study, cross-border capital flow data are collected and organized under the standard sub-aggregates of equity and debt flows. Figure 1 provides a taxonomic portrayal of the major and minor global funding components covered. Due to space considerations, seven different data series for which the compositional structures are shown in the figure are identified for focus: total capital flows, total equity flows, total debt flows, foreign direct investment (FDI), foreign portfolio equity investment (FPEI), short-term debt flows and long-term debt flows. The items and information beyond the third level (i.e. after the node 'by debtor') are given for illustrative purposes only.

\section{[Figure 1]}

Aggregate total net capital flows for a country group is the sum of total net equity and debt flows to that group. International aid allocations (concessional loans and grants), IMF credits, non-residents' deposits and interest arrears on external debt are excluded. Total equity inflows comprise net flows of FDI and FPEI. Foreign direct investment refers to the net financial investments that involve acquisition of a lasting management interest (10 percent or more of voting stock) in an enterprise operating in an economy other than that of the investor. $^{2}$ It is the sum of equity capital, reinvested earnings and other long-term and shortterm capital of similar character. FPEI includes net inflows from equity securities other than those recorded as direct investment, inflows from traded shares, stocks, depository receipts (American or global) and direct purchases of shares in local stock markets by foreign investors. Long-term and short-term debt inflows add up to the total net debt flows. Longterm debt inflows are disbursements minus principal repayments on private nonguaranteed (PNG) and public and publicly guaranteed (PPG) debt securities (e.g. publicly issued and privately placed bonds) and international loans (official and private non-concessional) with an original or extended maturity of more than one year and that are repayable in foreign

\footnotetext{
${ }^{2}$ Both the initial transactions that set up the relationship between the investor and the enterprise and all the subsequent transactions that take place between them and among affiliated enterprises such as subsidiaries (a non-resident investor owns more than 50\%), associates (an investor owns 50 percent or less) and branches (entirely or jointly owned unincorporated enterprises) are recorded as FDI.
} 
currency, goods or services. Net short-term debt flows consist of disbursements less principal repayments on loans, trade credits and negotiable money market debt instruments (such as repos, treasury bills, commercial and financial papers, bankers' acceptances, certificates of deposit and other short-term notes issued under the note issuance facilities that render the bearer the unconditional right to receive a contractually stipulated, reserved and fixed sum of money on a specified date) with an original maturity of one year or less.

Following the convention in World Bank (2008), I construct the 'net' aggregate capital flow indicators by summing up net annual credit (if the balance of the flow is positive) or debit (if it is negative) of the relevant liability accounts in the balance of payments. A positive numeric figure for a given year, therefore, implies that the financial liability items end up with a net inflow in that year, while any negative amount would reflect a net outflow for the year. By this practice, I concentrate on the foreigners' financial claims on the country group receiving the funding and ignore those of the domestic residents on foreign entities.

The data are usually expressed either in nominal billions of US dollars (USD) or as percent of the group's gross domestic product (GDP), unless otherwise stated. Nominal values are reported to show the actual realizations (i.e. the data) as they are. It is crucial to consider these values, as they are the essential or base data of interest throughout the paper. The primary focus is on nominal values because these figures have actual meaning in that international financial transactions originally bear these monetary values. In contrast to some economic and financial indicators or accounts (e.g. GDP), these values are not attached or assigned by statisticians but perpetually reported through the relevant money and capital market security accounts. The pertinent recordings in the balance of payments follow crude realizations and market activities which are mostly denominated in US dollars. Furthermore, it is the standard treatment in the periodic reports of multilateral organizations and in some academic articles when they review this kind of data (World Bank, 2012, Bosworth and Collins, 1999).

Wealth or income scaling is performed to take relative economic sizes or masses, exchange-rate movements and domestic price changes into account, along with real GDP growth. ${ }^{3}$ It also improves the accuracy and reliability of the comparisons across country groups, as the changing number of countries and observations for each group could bias the

\footnotetext{
${ }^{3}$ For more on this, see World Bank (2008). It should be noted, however, that the emphasis in this paper is on trends and developments in capital flows that are characterised by the changes in capital flows themselves. For the GDP-scaled data, changes in percentages over time would also be affected by the changes in GDP.
} 
comparisons based on nominal values. Hence, GDP-scaled data are preferred in comparing geographical regions and income groups. Currency conversion, aggregation and gap-filling procedures of the World Bank are adopted and applied for some years in some cases.

The paper proceeds as follows. Section 2 focuses on trends and developments in capital flow aggregates, whilst Section 3 reviews the level and direction of foreign direct and portfolio equity investments. The evolution and financial implication of international lending are covered in Section 4 and the key observations are summarized in Section 5.

\section{Trends and Developments in Aggregate Capital Flows}

I describe the level, composition and direction of global financial flows to developing countries for the period 1970-2006. The moving averages of total net capital flows and aggregate components are provided in Table 1. For all developing countries, total capital inflows jumped from about $\$ 13$ billion a year to the nominal level of $\$ 350$ billion within three decades. Modest during the initial years, total net equity flows have experienced the most outstanding rise by ending up with average annual inflows of almost $\$ 262$ billion. Debt flows rose very little and fell below 1\% of GDP in the most recent sub-period. Although capital flows as a share of GDP are variable throughout, in these terms total net capital flows doubled and total equity inflows rose by more than six times eventually.

[Table 1]

The period-averages of total capital and equity inflows are always, while those of debt inflows are almost always, positive (except for MENA during 1995-99 and for SSA during the last two sub-periods). This shows that external funding is a persistent and prevalent reality for developing economies and a manifestation of continual investor and creditor interest in them. The individual sub-periods of 1975-79 and 1990-94 witness remarkably higher surges that are driven by debt inflows in the former and by equity inflows in the latter. Economic slowdown in advanced countries could have contributed to both surges, while surges during the second episode may additionally be linked to concomitant liberalizations in developing countries. Total capital inflows were dwarfed by paralyzed debt inflows during 1985-89 due most probably to the Latin American debt crisis that had broken out one subperiod earlier. The effects of 1997 East Asian financial crisis are not that visible from this table. Initially strong in receiving foreign capital, Latin America and Caribbean loses its position to other regional destinations like Developing Asia and particularly Europe and 
Central Asia where debt flows most in the latest sub-periods. Middle East and North Africa and Sub-Saharan Africa have weak capital flows that remain under \$20 billion per year.

Figure 2 shows the distribution and evolution of aggregate capital inflows over time. Foreign borrowing and financial investments in developing countries have risen from relatively low levels to unprecedented amounts within nearly 40 years, approaching to $\$ 750$ billion in nominal terms. However, this escalation was not monotonic. Lending driven crossborder financing, displaying largely similar profile across geographical regions, has increased rather gradually until 1980s. It is depressed throughout this decade because of debt problems and international credit dry-up in some LAC countries (i.e. Latin American debt crisis that started in 1982). Financial integration, capital account liberalization and privatization of the late 1980s have facilitated and accelerated the international investment process that has led net capital flows to escalate. Exceeding aggregate net debt flows from early 1990s onwards, aggregate net equity flows have acted as a lean-against-the-wind in keeping total capital inflows uninhibited from devastating impacts (visible in this figure) of the contagious East Asian financial crisis that started in 1997 and resulted in lingering debt overhangs in most of the regions. ${ }^{4}$ Relative to GDP however, the rise is less impressive and regular, given growth of GDP and depreciation of the US dollar against some developing country currencies.

[Figure 2]

Aggregate debt flows are more volatile than aggregate equity flows, making the former responsible for much of the fluctuations in total capital flows. Regarding the individual regions, note that total debt flows to DA have never been more than $3 \%$ of GDP. This low level of dynamic external leverage of the region coincides with the conventional view that economic and financial fundamentals of Developing Asian countries had not, in fact, deteriorated to the extent of giving rise to a crash, which happened nonetheless. Second and third generation models of financial crises have, therefore, been devised to address this sort of anomaly by incorporating the investor behaviour, capital market imperfections and systemic inefficiencies (balance sheet distortions, deposit insurance schemes etc.) into their formulations. ${ }^{5}$ Europe and Central Asia is the region where debt flows shape the total capital flows-that ultimately achieve a high GDP share, being over $10 \%$ as of 2006 -for the majority of years. As most of the heavily indebted poor countries (HIPC) are in Sub-Saharan Africa,

\footnotetext{
${ }^{4}$ Contagion in 1990s with special emphasis on East Asian financial crisis is documented in Fratzscher (2003) and Caramazza et al. (2004).

${ }^{5}$ See Frankel and Wei (2005), Burnside et al. (2008).
} 
the apparent downward course of the region's SDF over time mirrors the effects of debt reduction and restructuring policies in these countries. International equity flows to SSA, albeit quite unstable, increasingly compensate for any possible shortfall in foreign financing due to borrowing constraints in the region. Following the new millennium, Middle East and North African capital flows in the last year and Latin American and Caribbean capital flows for a couple of years has diminished.

\section{[Figure 3]}

To enable more explicit comparisons among different country groups, four panels of bar graphs of the aggregate capital flow component averages are presented in Figure 3. According to nominal evaluations, Developing Asia, followed by LAC and ECA, ranks the first among five geographical regions in getting total capital and equity flows. Most of the aggregate debt inflows go to Europe and Central Asia. However, Latin America and Caribbean has the highest GDP shares in all categories. The other difference is that equity flows stand out to be the dominant aggregate component in Panel (a), whereas they are slightly superseded by debt flows in (b). These differences are most probably due to the valuation effects (exchange rate and price level changes) that are uncontrolled in Panel (a). As the exchange rate movements and price level changes may cause the later or recent period data to dominate the averages in nominal panels, GDP-scaled panels are believed to provide more accurate and consistent comparisons. Nonetheless, there is a common aspect of both panels in that the positions of MENA and SSA as being the least popular foreign capital destinations remain unaltered. The plain truth discernible from the lower half of the figure is that the global funds are lower in lower income countries. Cross-border capital moving to developing world, which is already meagre as most of the average GDP shares are well below $3 \%$, seems to be channelled mainly to the upper middle income country (emerging or richer developing) markets. ${ }^{6}$

Growth rates and cyclicality measures of capital flows to developing countries are reported in Table 2. For the purpose of assessing relative growth performances, Panel (a) gives average and median annual percentage changes in aggregate real capital flows, real GDP, international reserves (RES) and total external debt (TED) stocks (all in fixed 2005 US dollars). As capital flows are year-on-year changing net foreign liabilities, they are more dynamic and have higher growth rates than memorandum items (GDP, RES and TED).

\footnotetext{
${ }^{6}$ The wealth bias in international capital flows, their role in global macroeconomic (non)convergence and interactions with institutional quality levels are studied in Keskinsoy (2017a and 2017b).
} 
Setting total capital flows to LIC and total debt flows to LAC, MENA and LIC aside, all of the real capital flow aggregates grow. Real debt flows to low income countries and to Middle East and North Africa are shrinking. Reading negative medians and positive means respectively, note that total capital flows to low income countries and total debt flows to Latin America and Caribbean are characterized by weak but frequent ebbs and intermittent but torrential flows, so that whether they are actually growing or contracting is difficult to tell. While growth in equity flows is more regular and steady, in debt flows, by and large, it is bulky and lumpy. All memorandum items, even cumulative external debt stocks, grow everywhere. The positive growth of TED in LIC and MENA-where the mostly private debt inflows were dwindling-is perhaps because of undisbursed credit commitments, concessional loans, interest arrears and IMF credits. Faster accumulation of total external debt than real output is likely to be accommodated by even faster build-up of external reserves, which are in turn fed by capital inflows. Considering the means and medians, all forms of capital flows to developing economies in Europe and Central Asia appear to have the highest compound growth rates.

[Table 2]

The correlations between annual percentage changes in the capital flow aggregates and in the real GDP that are used to measure the cyclicality of these real aggregates are provided in Panel (b) of the table. In general, total capital flows and its aggregate components are acyclical with a few exceptions; total net capital and equity flows to UMIC, aggregate equity and debt flows to LAC and aggregate net debt flows to LMIC and DA are procyclical. Two implications are worth to mention. First, no countercyclicality is observed in capital flows. Second, of the detected procyclicality the most is in the total debt flows.

\section{Trends and Developments in Equity Flows}

A data summary on total net, direct and portfolio equity flows to developing countries is given in Table 3. As reasonably expected, a quick scan of the entire table indicates that aggregate equity inflows and FDI are all, and FPEI is mostly, positive. In case of all developing countries, I see a virtually exponential increase in aggregate equity inflows as they are up from $0.5 \%$ of GDP per year to $3.1 \%$ over the $1970-2006$ period. The yearly average inflows of FDI reached nearly to $\$ 225$ billion, whilst the equity funds that have been created by share purchases of foreign portfolio investors soared from almost nil levels (e.g. $\$ 400,000)$ to $\$ 37$ billion a year. Although every type of nominal equity inflows goes up 
continuously (even more rapidly after 1980s as a result of economic and financial liberalization, integration, capital market establishment and privatization), their GDP proportions do not always follow an increasing pattern-they were smaller than or equal to $0.5 \%$ during the pre-1990s and showed consecutive increases only in case of total and direct equity flows thereafter. Average annual GDP share of foreign portfolio equity investments in developing markets has never transcended $0.4 \%$. As a matter of compositional evaluation, total equity flows have been shaped almost completely by FDI throughout the initial two decades and still FDI has wheeled them over the remaining years.

[Table 3]

The equity inflows, again in nominal terms, to MENA and SSA that have been getting smaller in volume due to the lower velocity made these regions the ultimate losers against the other two such as DA and ECA whose performances in attracting foreign equity capital have been overwhelming, particularly in the post-1980s. The competitive allocation among regions would then translate into 'who gets more' instead of 'who loses more'. For instance, Latin America and Caribbean (Europe and Central Asia) that was getting largest (smallest) volumes for the first fifteen years has seen its position changed afterwards. It is noteworthy that SubSaharan Africa is not only the region which had available FPEI data at the outset but also it is the one that has the highest GDP shares for total and portfolio equity inflows (in the most recent decade). The drastic variations in nominal and scaled FPEI flows-having the only negative figures in the table-might be taken as a clue for the sheer speculative activity in SSA stock markets.

On an annual basis, the net foreign direct and portfolio equity flows to developing countries that were on an upward trajectory after the early 2000s have finally arrived at about $\$ 400$ billion and $\$ 100$ billion respectively (Figure 4). Albeit with varying sizes, nominal inflows follow rising trend towards the end of the period in all regions but Latin America and Caribbean. To rephrase the FDI dominance in total equity flows, FPEI is greater than FDI in just two instances; in LAC, 1993 and in SSA, 1998. The adverse effects of currency and banking crises on global equity flows are also traceable in this figure. Although total and direct equity flows never fall below zero and hence do not pose any outflow, they are reduced by the Latin American debt crisis in early 1980s (distinguishable in ADC and LAC graphs) and by other regional or country level crashes in certain years from the mid-1990s onwards (Mexican, East Asian, Russian, Brazilian, Turkish and Argentine financial mayhems in 1994, 1997, 1998, 1999, 2001 and 2002 respectively). Net outflows on foreign equity investments, 
however, can only be seen in FPEI for at least a year in any geographical region (SSA has the most of such cases, for example). Furthermore, it seems that FPEI flows deteriorate concurrently with the beginning of the crisis, whereas deterioration in FDI flows comes with some lag following the crisis.

\section{[Figure 4]}

Figure 5 shows how the aggregates and components of cross-border equity flows are distributed among different country groups. According to Panel (a), Developing Asia has the largest share in nominal FDI and portfolio equity flows as well as in aggregate equity flows. As in Figure 3, GDP scaling changes the order of distribution and pulls Latin America and Caribbean up to the highest echelon in SEF and SFDI and to the second highest in SFPEI, after Sub-Saharan Africa. Panel (b) also demonstrates that developing regions have more evenly distributed foreign equity investments relative to their output. The only regularity observed across the top panels of the figure is that Middle East and North Africa has the lowest shares in all three categories. The panels at the bottom, again similar to Figure 3 , uniformly indicate the existence of income bias in international portfolio and direct equity investments in developing countries. Moreover, I see from the percentage averages (being as little as around 1.5 or less) in the right panels of the figure that these investments are still well under the economic potential of the countries at the periphery.

\section{[Figure 5]}

The compound growth rates of and cyclicality statistics for real equity inflows are reported in Table 4. On average, aggregate net equity flows have an annual growth rate of about $10 \%$ or more in every country group. Real portfolio equity and FDI flows to all country groups but Sub-Saharan Africa are growing positively, and the former has much faster growth. Since foreign direct and portfolio equity investments tend to fluctuate in SSA, the trends are ambiguous. Europe and Central Asia (among the regions) and lower middle income countries (from the income groups) appear to have the most buoyant equity finance. Correlations between yearly growth rates of real GDP and equity flows reveal that, as for aggregates above, all types of external equity flows are generally acyclical. As there is no significantly countercyclical flow, real equity inflows (all three) to LAC and direct and total equity flows to UMIC are the only procyclical flows.

[Table 4] 
Foreign contribution to gross domestic investment (GDI) in developing countries was, on average, around 5.5\% a year within the period 1970-2006 (Figure 6). This implies that the extent of multinational involvement in domestic capital formation at the periphery has been limited. ${ }^{7}$ Among the three regions with above average shares, Europe and Central Asia achieves the highest involvement at nearly $10 \%$, being roughly three percentage points above the next region (Latin America and Caribbean). It is surprising that Developing Asia comes out to be the least popular investment location for foreigners and that even Middle East and North Africa outstrips it in this regard. Notwithstanding the fact that differences among income groups are less pronounced, the FDI portion of GDI is biggest in emerging economies and, peculiarly, it is bigger in low income countries than the countries of the income group in the middle. Except for the second sub-period, the ratio is increasing over time, with a marked acceleration in the post-1980s.

\section{[Figure 6]}

Figure 7 compares the non-resident participation in developing-country domestic stock markets across the regions and over time. Apart from the Middle East and North Africa which has the lowest share, foreign participation has been relatively balanced throughout the regions. Taking the rate of participation for ADC as an indicator and bearing the definitions of foreign portfolio equity inflows and domestic stock market capitalization in mind (such as that the former additionally includes depository receipts), I estimate that international investors would have weighted developing country assets in their portfolio at an average rate of about $1 \%$. This confirms the common view that developing and emerging market equities are underweighted in global portfolios as a result of home bias and lack of diversification. ${ }^{8}$ Because there was no stock exchange in every country until the late 1980s I could not depict the proportions for the first 15 years. Once the bourses are properly established, the nonresident engagement began to materialize and stood above $1.5 \%$ per year during the initial episode (which is very close to the estimate of Bekaert et al. (2002) who find that, after the liberalization, foreign portfolio equity flows increase by $1.4 \%$ of market capitalization); overshooting by $2 \%$ in the first half of 1990 s has subsequently declined.

\section{[Figure 7]}

\footnotetext{
7 In a partially similar vein, Aizenman et al. (2007) find that just $10 \%$ of the domestic capital stock in developing countries has been externally financed throughout the 1990s.

${ }^{8}$ See Chan et al. (2005), Obstfeld and Rogoff (2000), Tesar (1999), Stulz (1999), Baxter and Jermann (1997).
} 


\section{Trends and Developments in Debt Flows}

External debt flows to developing countries have been more variable than equity flows over the period 1970-2006. The episodes of upward surges have been interrupted by the next episodes of slumps or decelerations because of either financial crises or voluntary and discretionary debt reduction policies in different countries. Although these structural breaklike episodes were transitory in some countries, they could have been rather prolonged in others. The overall observation is that the volumes of cross-border lending have recorded higher amounts at the end of the period than at the beginning, although this is not the case when expressed relative to income.

A factual synopsis of the total, long-term and short-term debt movements is provided in Table 5. Within about four decades, average annual short-term debt inflows soared from $\$ 2$ billion to $\$ 46$ billion; a 23-times increase that ultimately put the short-term debt flows ahead of the long-term debt flows in the last sub-period. The enlargement in total and long-term debt inflows has been relatively smaller, even though they had no outflows (i.e. always being positive, on average and for all developing countries) unlike short-term debt inflows. Aggregate nominal foreign borrowing has risen in all sub-periods but 1985-89 when it decreased as a result of Latin American debt crisis. In US dollar denominations, long-term foreign borrowing has behaved similarly but it decreased in the last sub-period, reflecting the adverse effects of financial crises in East Asia and in some other developing countries that had taken place earlier. Voluntary debt restructuring and reduction operations might also have contributed to this diminution. The declines in nominal short-term net foreign borrowing have occurred during the same sub-periods when the crises erupted. To stylize the fact that has become clear so far, I note that the deterioration in short-term debt inflows goes along with the advent of the crisis whilst long-term debt inflows degenerate with some lag after the crisis. This sequential process, which is similar to the one in equity flows described before, largely continues during the recovery phase after the crisis. Following the peak in the second half of the 1970s, all forms of debt flows as a percentage of GDP have fluctuated but never attained their pre-1980 levels, even below 1\% in the most recent sub-period.

[Table 5]

Net outflows are detected in some regions. As the table shows the rolling averages but not the exact yearly realizations, the negative incidences are quite few. Clustering of outflows in the last decade could be explained by the debt reduction decisions (more repayment and less 
new borrowing) rather than contagious currency and banking crises. There are two reasons behind this argument; the first is that the most numerous outflows occurred in Sub-Saharan Africa and Middle East and North Africa which are the regions without any notorious financial crashes, and the second is that the number of outflows is the same across the two sub-periods of which the latter does not include as many crises as does the former. Only in Developing Asia are short-term debt outflows during a crisis period (1995-99) succeeded by long-term debt outflows in the next period. Being the most active region that has got everincreasing external debt funding, Europe and Central Asia saw outflows on its short-term debt twice. First was during the Latin American debt crisis and the second was during the sub-period 1990-94 that includes several prominent transformations and upheavals like the dissolution of the USSR, the Gulf War and the 1994 Turkish currency crisis. ${ }^{9}$ The retardation processes in Latin America and Caribbean have been symmetrical in the sense that block declines in all types of debt inflows have been preceded by the initial drops in short-term debt inflows (disrupted by the corresponding crisis) that eventually turned out to be net outflows. Being always positive and driving the flow of external lending after 1980s, short-term debt flows to Africa and Middle East did not contribute to total debt outflows which are rather produced by consecutive plummets in long-term debt flows to these regions.

Figure 8 shows the 37-year progression of foreign borrowing in developing countries. Within this period, total debt inflows have risen to about \$225 billion which is less than even half of the same-year value of total equity inflows in Figure 4 and just equal to the seventh sub-period average of FDI in Table 3. This implies that the pace of increase in debt flows has been much slower than equity flows. There are many factors that might have badly influenced the influx of international debt capital to a developing economy. Deteriorating macroeconomic fundamentals (like chronically high inflation rates, unsustainable internal and external balances, inadequate foreign reserves etc.), debt overhang, credit rationing and negative investor sentiments that either lead to financial crises or urge the economic agents to reduce their indebtedness could be identified as the main factors. Besides these structural failures, factors like asymmetric information, moral hazard and costly state verification that

\footnotetext{
${ }^{9}$ The fact that capital flows to Turkey constitute almost one fifth of the aggregate capital flows to Europe and Central Asia (not explicitly reported) shows the determining role of that country for the whole region.
} 
are nearly intrinsic to the real functioning of international capital markets may create systemic failures (or risks) that ultimately result in credit crunches. ${ }^{10}$

\section{[Figure 8]}

The effects of such factors could be traced explicitly in Figure 8. The steady increase in all types of external borrowing of developing countries during 1970s has been depressed by the Latin American debt crisis at the beginning of the next decade. Despite the fact that only short-term debt gave outflows, the depression in every component lingered for almost a decade. Apart from the curtailing in 1994 due to Mexican and Turkish currency crises, the resumption in late 1980s has continued until the 1997 East Asian financial turmoil. The outflows on short-term debt that approximately amounted to $\$ 45$ billion in the following year showed the first severe sign of the turmoil. As a result of the periodic and spatial contagion, the net foreign borrowings (which have already been hampered) stopped completely and recorded net reimbursements as of 2002. Thereafter, the final rebound came in and pushed them to successively higher levels. Output shares of debt inflows have never repeated their previous gains and levels and stayed below 3\% in the majority of years. This is because the valuation effects put a wedge between the nominal and scaled flows. It is clearer from the line plots of the GDP proportioned series that short-term debt inflows go first in worseningrecovery cycle around the crisis periods and long-term debt inflows engage in the cycle later. They also indicate that long-term debt flows are at least as volatile as short-term debt flows.

[Figure 9]

The allocation of international lending among the developing country groups is presented in Figure 9. Rankings with respect to the nominal components shift within the top recipients. Once the economic mass is taken into consideration, LAC outperforms the other regions in receiving total and long-term debt. The SSTD bars which are nearly at the same length indicate that developing countries weight short-term foreign borrowing by their wealth at around 0.4. Overall, Sub-Saharan Africa has had the lowest share in global (private and nonconcessional) debt allocation. The larger the size of the economy the greater is the external debt capital it raises. As a structural matter, long-term debt flows dominate short-term debt flows and the latter is relatively closer to the former in SSA.

\footnotetext{
${ }^{10}$ The second line of factors, for instance, is thought to be the major trigger behind the financial crisis of the late $2000 \mathrm{~s}$ in advanced economies.
} 
In general, real debt inflows are growing (Table 6). Europe and Central Asia has the highest compound growth rates, whereas Middle East and North Africa has the lowest. In income groups, upper middle income countries have the most firmly growing debt inflows. Total debt flows to low income countries and long-term debt flows to lower middle income countries shrink. As per components, short-term debt grows more rapidly than long-term debt. Comparing Panel (b) in this table and in Table 4, acyclicality is less prevalent in debt flows than it was in equity flows. The most striking observation is that Europe and Central Asian debt flows (particularly short-term debt, at 5\% significance level) are countercyclical. This may safeguard economic entities in the region from the harms of excessive leverage that they tend to have. Real debt flows to DA, LAC and LMIC are procyclical. Of the significant cases, short-term debt flows are more (pro)cyclical than long-term debt flows.

[Table 6]

To give an idea about the cost and maturity structure of external borrowing in developing countries, Figure 10 demonstrates time series plots and comparative graphs of weighted average interest rates and years to maturity on new external debt commitments. Over 19702006 , the global averages of annual interest rate on and maturity of a public or publicly guaranteed loan have been about $6 \%$ and 18 years respectively. These figures, being relatively worse than they were at the beginning, clue tightened international lending conditions for developing countries over time.

[Figure 10]

The main distinction between interest and maturities is that they move in opposite directions for the majority of years. The gap widens particularly around the crises in such a way that as the interest rates hike years to maturity fall, putting the developing economy in further jeopardy. This opposite movement implies an inverted (i.e. quasi-convex) yield curve for the public or publicly guaranteed foreign credits. Higher growth rates of short-term debt flows corroborate this inference because an inverted yield curve exists when the demand for short-term funds (or the incentive to hold short-maturity securities) is greater than the demand for long-term funds (or the incentive to hold long-maturity securities). ${ }^{11}$ The inverted yield curve may also portend the rigidity in international money markets and the economic recession in developing markets, which were all witnessed during or in the aftermath of the Latin American and East Asian financial crises.

\footnotetext{
${ }^{11}$ See Turner (2002), Min et al. (2003).
} 
The reversion of interest rates, but not maturities (except for Latin America and Caribbean), to their pre-1975 levels in the final years constitutes the other distinction. This is also discernible in the lower half of Panel (c) where the interest rate actively rises throughout the first three sub-periods, peaks during the Latin American debt crisis and declines thereafter. Maturity, however, shows limited changes after the initial drop. The variation of maturities and interest rates across country groups mirrors the development objective behind the global lending (the upper part of Panel (c)).

\section{Conclusion}

This paper surveys the data on international capital flows to developing countries for the period 1970-2006. Developing countries are represented by either the most aggregate group of 'all developing countries', five geographical regions (Developing Asia, Europe and Central Asia, Latin America and Caribbean, Middle East and North Africa and Sub-Saharan Africa) or three income groups (upper middle income countries, lower middle income countries and low income countries). Trends and developments in seven fundamental capital flow aggregates (total capital flows, total debt flows, total equity flows, foreign direct investment, foreign portfolio equity investment, long-term debt flows and short-term debt flows) are discussed under different settings of these country groups. Because it is a review paper that uses alternative measures to present and discuss the data for several spatial groups and types of capital flow, it has a lengthy exposition.

Total net capital flows denominated in nominal US dollars have surged within about four decades. They were driven by total debt inflows in 1970s and by total equity inflows from 1990s onwards. Rising gradually before 1990s, FDI-shaped total equity inflows have soared thereafter due to financial globalization and liberalization. The overall increase in long-term debt-driven total debt inflows has been less impressive, because not only the financial crises outburst during the period (i.e. 1982 Latin American debt crisis, 1997 East Asian financial crash and many other country crises) severely hit them but they were also decreased as a result of voluntary and discretionary debt reduction policies. These crises dwarfed total capital inflows and depressed total equity inflows as well. Increases in capital inflows as a share of GDP have been more variable and modest. Nevertheless, similar episodes of ebb and flow as well as the compositional features are observed (though less evidently) in GDPscaled data. 
Among the regions, Latin America and Caribbean got the highest amount of foreign capital relative to its wealth during the four decades. Africa and the Middle East were the least popular developing market destinations. The other regions, Developing Asia and particularly Europe and Central Asia, have been the growing external fund recipients.

There was a strong wealth bias in foreign capital flows to developing economies as the lower income countries have always received less external debt and equity capital. 
Tables and Figures

Figure 1: Taxonomy of Global Capital Flows Considered

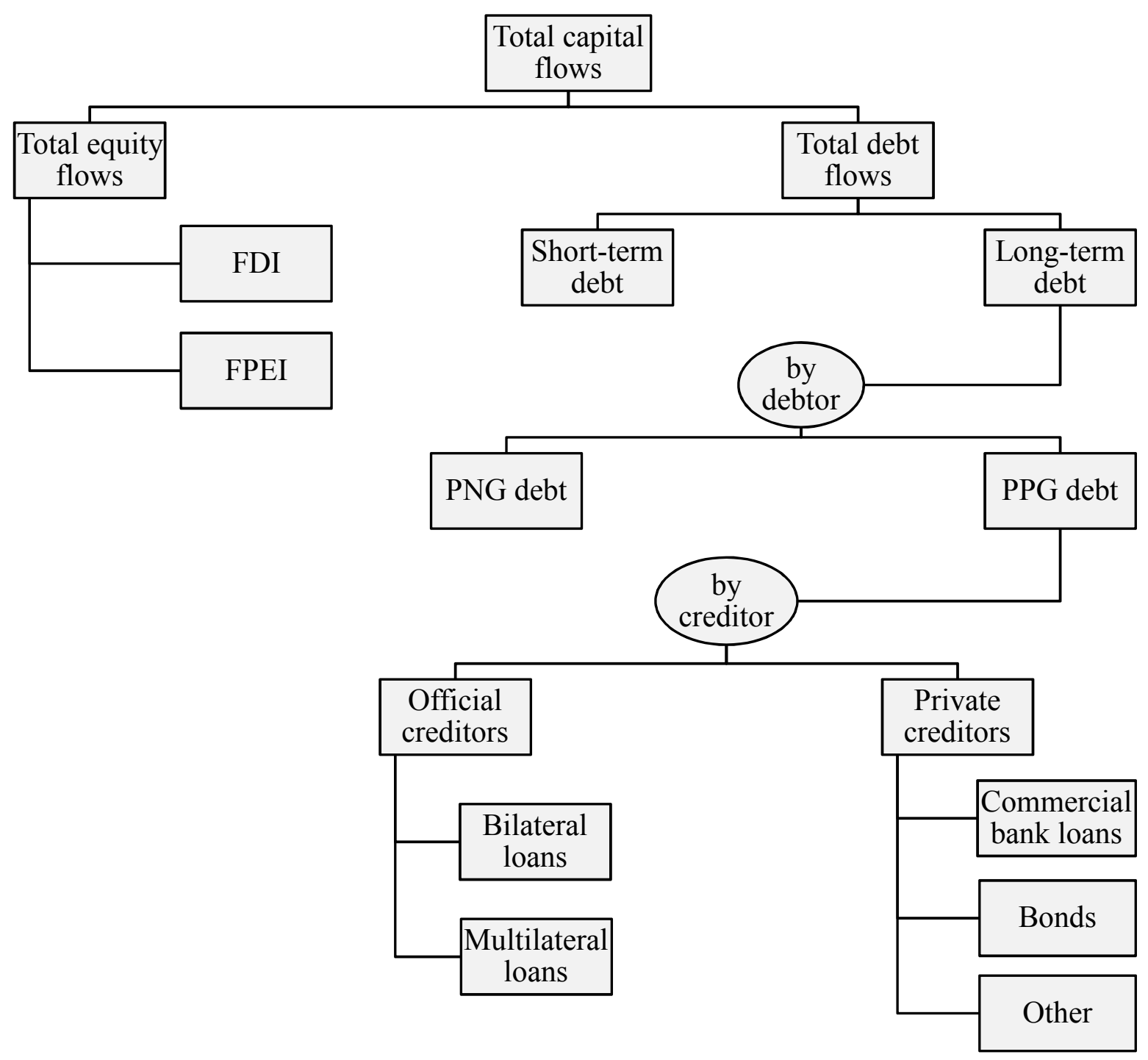

Sources: World Bank, Global Development Finance and author's depictions.

Notes: FDI denotes foreign direct investment and FPEI refers to foreign portfolio equity investment. Private nonguaranteed (PNG) debt comprises the external obligations of private debtors that are not guaranteed for repayment by a public entity of their country. Public and publicly guaranteed (PPG) debt covers the external obligations of public and private borrowers that are insured by a public entity. Bilateral creditors are governments and their agencies, including central banks, official export credit agencies and autonomous agencies. Multilateral creditors are international financial institutions such as the World Bank, regional development banks and other multilateral and intergovernmental agencies whose lending is administered on a multilateral basis. Commercial bank loans comprise loans from private banks and other private financial institutions. Bonds include publicly issued or privately placed bonds. Credits from 'other' private creditors contain credits by manufacturers, exporters and other suppliers of goods plus bank credits covered by a guarantee of an export credit agency. Foreign aid (i.e. concessional loans and grants), credits from the International Monetary Fund (IMF), non-residents' deposits and interest arrears on all sorts of debt are excluded. 
Table 1: Total Capital Flows to Developing World by Sub-periods, Billions of USD

\begin{tabular}{|c|c|c|c|c|c|c|c|}
\hline Region and Component & $1970-74$ & 1975-79 & 1980-84 & 1985-89 & 1990-94 & 1995-99 & 2000-06 \\
\hline \multicolumn{8}{|l|}{ All Developing Countries } \\
\hline Total Capital Inflows & $\begin{array}{r}13.42 \\
(2.0)\end{array}$ & $\begin{array}{r}48.59 \\
(3.9)\end{array}$ & $\begin{array}{r}64.69 \\
(2.0)\end{array}$ & $\begin{array}{r}45.11 \\
(1.2)\end{array}$ & $\begin{array}{r}127.27 \\
(3.1)\end{array}$ & $\begin{array}{r}236.86 \\
(4.2)\end{array}$ & $\begin{array}{r}349.02 \\
(4.0)\end{array}$ \\
\hline Total Equity Inflows & $\begin{array}{l}3.22 \\
(0.5)\end{array}$ & $\begin{array}{l}6.03 \\
(0.5)\end{array}$ & $\begin{array}{r}11.24 \\
(0.3)\end{array}$ & $\begin{array}{r}15.72 \\
(0.4)\end{array}$ & $\begin{array}{r}66.82 \\
(1.6)\end{array}$ & $\begin{array}{r}161.92 \\
(2.8)\end{array}$ & $\begin{array}{r}261.91 \\
\quad(3.1)\end{array}$ \\
\hline Total Debt Inflows & $\begin{array}{r}10.20 \\
(1.5)\end{array}$ & $\begin{array}{r}42.56 \\
(3.4)\end{array}$ & $\begin{array}{r}53.45 \\
(1.7)\end{array}$ & $\begin{array}{r}29.39 \\
(0.8)\end{array}$ & $\begin{array}{r}60.45 \\
(1.5)\end{array}$ & $\begin{array}{r}74.94 \\
(1.3)\end{array}$ & $\begin{array}{r}87.11 \\
(0.9)\end{array}$ \\
\hline \multicolumn{8}{|l|}{ Developing Asia } \\
\hline Total Capital Inflows & $\begin{array}{c}1.62 \\
(0.6)\end{array}$ & $\begin{array}{l}6.07 \\
(1.4)\end{array}$ & $\begin{array}{r}15.98 \\
(2.4)\end{array}$ & $\begin{array}{r}18.34 \\
(2.0)\end{array}$ & $\begin{array}{r}56.20 \\
(4.5)\end{array}$ & $\begin{array}{r}79.89 \\
(4.0)\end{array}$ & $\begin{array}{r}143.53 \\
(4.0)\end{array}$ \\
\hline Total Equity Inflows & $\begin{array}{c}0.35 \\
(0.1)\end{array}$ & $\begin{array}{c}0.72 \\
(0.2)\end{array}$ & $\begin{array}{l}2.44 \\
(0.4)\end{array}$ & $\begin{array}{r}6.00 \\
(0.7)\end{array}$ & $\begin{array}{r}29.99 \\
(2.3)\end{array}$ & $\begin{array}{r}63.92 \\
(3.2)\end{array}$ & $\begin{array}{r}116.33 \\
(3.3)\end{array}$ \\
\hline Total Debt Inflows & $\begin{array}{r}1.27 \\
(0.5)\end{array}$ & $\begin{array}{l}5.35 \\
(1.2)\end{array}$ & $\begin{array}{r}13.54 \\
(2.0)\end{array}$ & $\begin{array}{r}12.34 \\
(1.4)\end{array}$ & $\begin{array}{r}26.20 \\
(2.2)\end{array}$ & $\begin{array}{r}15.96 \\
(0.8)\end{array}$ & $\begin{array}{r}27.20 \\
(0.7)\end{array}$ \\
\hline \multicolumn{8}{|l|}{ Europe and Central Asia } \\
\hline Total Capital Inflows & $\begin{array}{l}1.01 \\
(\mathrm{n} / \mathrm{a})\end{array}$ & $\begin{array}{l}4.88 \\
(\mathrm{n} / \mathrm{a})\end{array}$ & $\begin{array}{r}6.47 \\
(0.5)\end{array}$ & $\begin{array}{r}7.19 \\
(0.4)\end{array}$ & $\begin{array}{r}12.29 \\
(1.7)\end{array}$ & $\begin{array}{r}37.99 \\
(3.6)\end{array}$ & $\begin{array}{r}108.50 \\
(5.6)\end{array}$ \\
\hline Total Equity Inflows & $\begin{array}{l}0.14 \\
(\mathrm{n} / \mathrm{a})\end{array}$ & $\begin{array}{l}0.25 \\
(\mathrm{n} / \mathrm{a})\end{array}$ & $\begin{array}{r}0.52 \\
(0.04)\end{array}$ & $\begin{array}{l}1.02 \\
(0.1)\end{array}$ & $\begin{array}{r}5.40 \\
(0.7)\end{array}$ & $\begin{array}{r}17.56 \\
(1.7)\end{array}$ & $\begin{array}{r}49.43 \\
(2.6)\end{array}$ \\
\hline Total Debt Inflows & $\begin{array}{l}0.87 \\
(\mathrm{n} / \mathrm{a})\end{array}$ & $\begin{array}{l}4.63 \\
(\mathrm{n} / \mathrm{a})\end{array}$ & $\begin{array}{r}5.94 \\
(0.5)\end{array}$ & $\begin{array}{r}6.17 \\
(0.4)\end{array}$ & $\begin{array}{r}6.90 \\
(1.1)\end{array}$ & $\begin{array}{r}20.43 \\
(1.9)\end{array}$ & $\begin{array}{r}59.07 \\
(3.0)\end{array}$ \\
\hline \multicolumn{8}{|c|}{ Latin America and Caribbean } \\
\hline Total Capital Inflows & $\begin{array}{l}8.21 \\
(3.3)\end{array}$ & $\begin{array}{r}27.04 \\
(5.6)\end{array}$ & $\begin{array}{r}31.60 \\
(4.0)\end{array}$ & $\begin{array}{r}9.75 \\
(1.2)\end{array}$ & $\begin{array}{r}51.15 \\
(3.8)\end{array}$ & $\begin{array}{r}105.27 \\
(5.4)\end{array}$ & $\begin{array}{r}69.41 \\
(3.2)\end{array}$ \\
\hline Total Equity Inflows & $\begin{array}{r}1.50 \\
(0.7)\end{array}$ & $\begin{array}{l}3.34 \\
(0.7)\end{array}$ & $\begin{array}{r}6.13 \\
(0.8)\end{array}$ & $\begin{array}{r}6.07 \\
(0.8)\end{array}$ & $\begin{array}{r}27.44 \\
(2.0)\end{array}$ & $\begin{array}{r}65.35 \\
(3.4)\end{array}$ & $\begin{array}{r}68.90 \\
(3.2)\end{array}$ \\
\hline Total Debt Inflows & $\begin{array}{l}6.71 \\
(2.7)\end{array}$ & $\begin{array}{r}23.70 \\
(4.9)\end{array}$ & $\begin{array}{r}25.47 \\
(3.2)\end{array}$ & $\begin{array}{r}3.68 \\
(0.5)\end{array}$ & $\begin{array}{r}23.70 \\
(1.8)\end{array}$ & $\begin{array}{r}39.92 \\
(2.1)\end{array}$ & $\begin{array}{r}0.51 \\
(-0.03)\end{array}$ \\
\hline \multicolumn{8}{|c|}{ Middle East and North Africa } \\
\hline Total Capital Inflows & $\begin{array}{c}0.93 \\
(1.9)\end{array}$ & $\begin{array}{l}6.10 \\
(4.5)\end{array}$ & $\begin{array}{l}4.22 \\
(1.8)\end{array}$ & $\begin{array}{l}4.87 \\
(1.8)\end{array}$ & $\begin{array}{r}4.97 \\
(1.9)\end{array}$ & $\begin{array}{r}1.48 \\
(0.4)\end{array}$ & $\begin{array}{r}10.78 \\
(2.0)\end{array}$ \\
\hline Total Equity Inflows & $\begin{array}{c}0.37 \\
(0.7)\end{array}$ & $\begin{array}{c}0.95 \\
(0.7)\end{array}$ & $\begin{array}{r}1.07 \\
(0.5)\end{array}$ & $\begin{array}{r}1.34 \\
(0.5)\end{array}$ & $\begin{array}{l}1.91 \\
(0.7)\end{array}$ & $\begin{array}{r}2.75 \\
(0.7)\end{array}$ & $\begin{array}{r}10.35 \\
(1.8)\end{array}$ \\
\hline Total Debt Inflows & $\begin{array}{r}0.56 \\
(1.2)\end{array}$ & $\begin{array}{l}5.15 \\
(3.8)\end{array}$ & $\begin{array}{l}3.16 \\
(1.4)\end{array}$ & $\begin{array}{r}3.53 \\
(1.3)\end{array}$ & $\begin{array}{l}3.06 \\
(1.2)\end{array}$ & $\begin{array}{l}-1.27 \\
(-0.3)\end{array}$ & $\begin{array}{c}0.43 \\
(0.2)\end{array}$ \\
\hline \multicolumn{8}{|l|}{ Sub-Saharan Africa } \\
\hline Total Capital Inflows & $\begin{array}{c}1.66 \\
(1.9)\end{array}$ & $\begin{array}{l}4.51 \\
(2.6)\end{array}$ & $\begin{array}{c}6.43 \\
(2.5)\end{array}$ & $\begin{array}{r}4.95 \\
(1.8)\end{array}$ & $\begin{array}{c}2.66 \\
(0.9)\end{array}$ & $\begin{array}{r}12.24 \\
(3.7)\end{array}$ & $\begin{array}{r}16.81 \\
(3.1)\end{array}$ \\
\hline Total Equity Inflows & $\begin{array}{r}0.85 \\
(1.0)\end{array}$ & $\begin{array}{c}0.78 \\
(0.5)\end{array}$ & $\begin{array}{l}1.09 \\
(0.4)\end{array}$ & $\begin{array}{r}1.28 \\
(0.5)\end{array}$ & $\begin{array}{r}2.07 \\
(0.7)\end{array}$ & $\begin{array}{r}12.34 \\
(3.7)\end{array}$ & $\begin{array}{r}16.91 \\
(3.4)\end{array}$ \\
\hline Total Debt Inflows & $\begin{array}{r}0.80 \\
(0.9)\end{array}$ & $\begin{array}{l}3.73 \\
(2.1)\end{array}$ & $\begin{array}{l}5.34 \\
(2.1)\end{array}$ & $\begin{array}{r}3.67 \\
(1.4)\end{array}$ & $\begin{array}{c}0.58 \\
(0.2)\end{array}$ & $\begin{array}{r}-0.10 \\
(-0.03)\end{array}$ & $\begin{array}{l}-0.10 \\
(-0.3)\end{array}$ \\
\hline
\end{tabular}

Sources: World Bank, World Development Indicators, Global Development Finance.

Notes: Including the numbers in parentheses which are the inflows expressed as percent of regional gross domestic product (GDP), all nominal figures in the table are averages for the corresponding period and country group or region. Data for all developing countries consist of the individual sums of regional data. South, East and Pacific Asian developing countries are combined within Developing Asia, while Europe and Central Asia covers so-called transition economies in Central Asia and Eastern Europe as well as Mongolia. The remaining regions are the same as in World Bank classifications. N/A means not available. See also notes to Figure 1. 
Figure 2: Aggregate Net Capital Flows to Developing World by Regions, 1970-2006
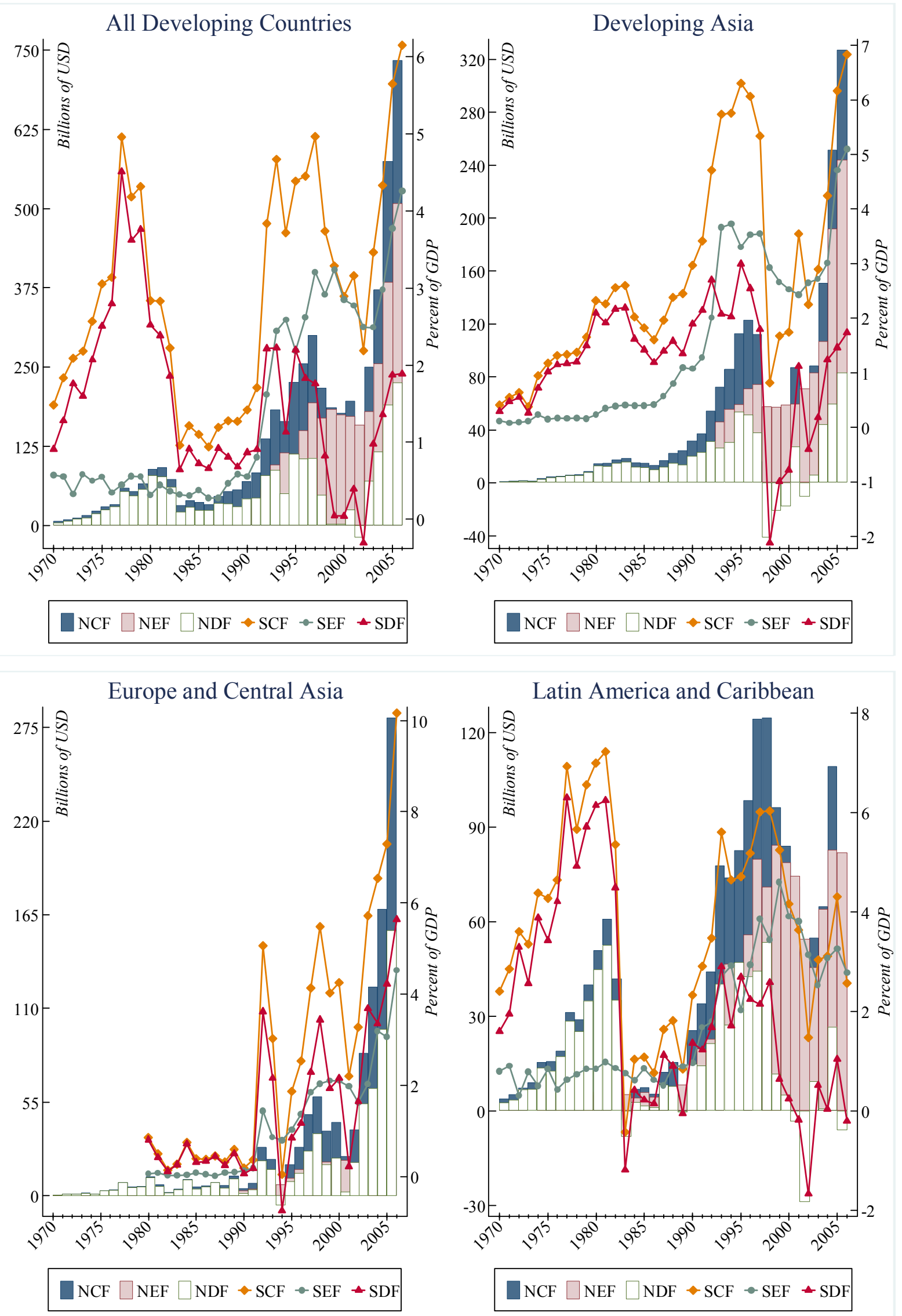

(continued on next page) 
Figure 2 (continued)

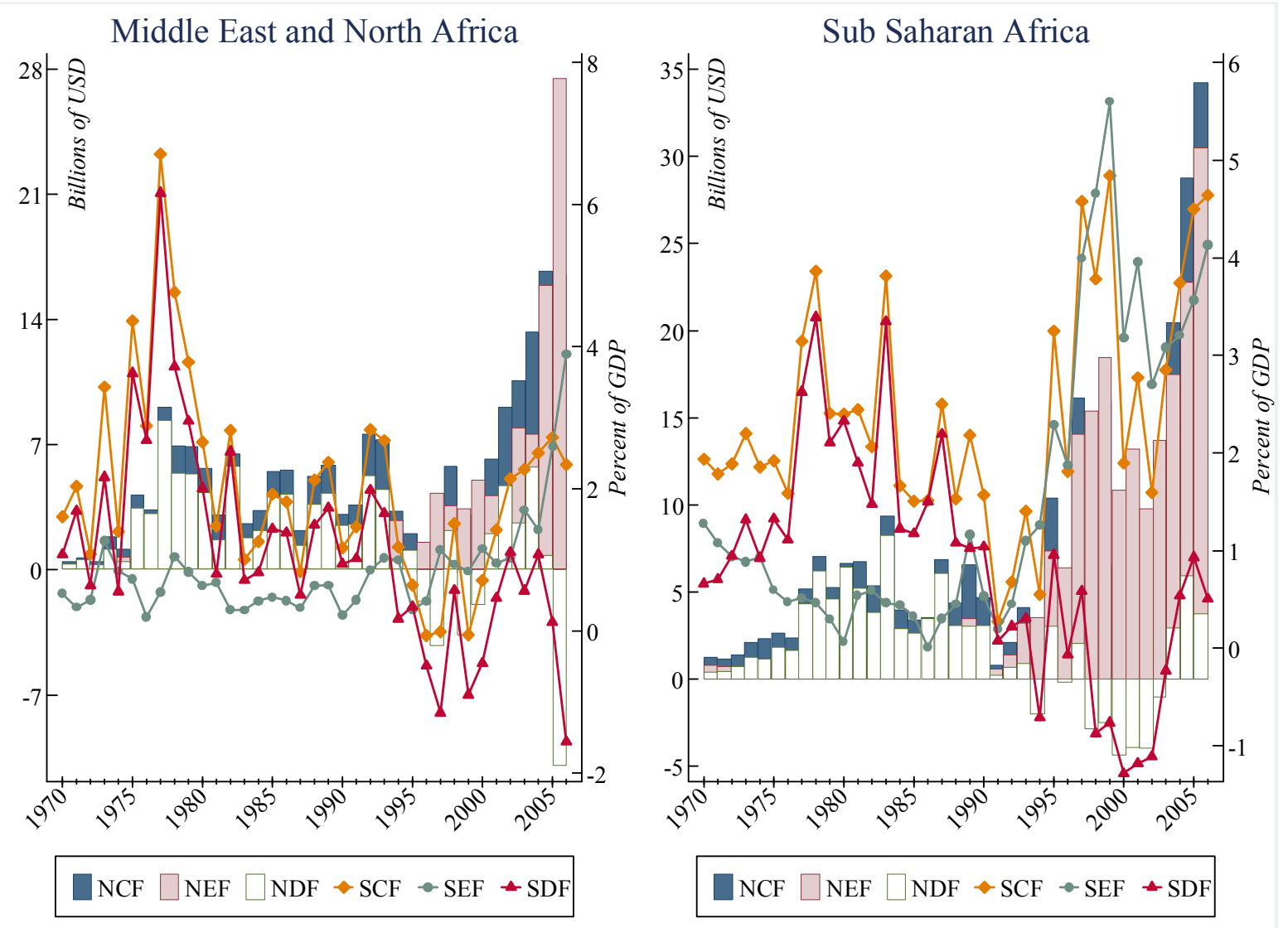

Sources: World Bank, World Development Indicators, Global Development Finance.

Notes: Bars show the nominal levels of aggregate net capital flows which are in current U.S. dollars (left axis), whilst lines indicate the percentage amounts for the same flows that are scaled by current GDP (right axis). The common letters, $N$ and $S$, at the beginning of the legend labels denote 'nominal' and 'scaled' respectively. CF refers to (aggregate) capital flows, EF is equity flows and DF stands for debt flows. Only white bars exactly match their legends (both keys and labels), whereas light and dark shaded bars represent their labels partly. The true NCF for a year is the vertical sum of all the bars within that year and the true NEF is what remains from the white bar (NDF) in a certain year. Light shaded bars exhibit merely the amount of NEF in excess of NDF when both have the same signs and they show the whole NEF when the signs are opposite. See notes to Table 1. 


\section{Figure 3: Distribution of Capital Inflows by Geographic Regions and Income Groups}

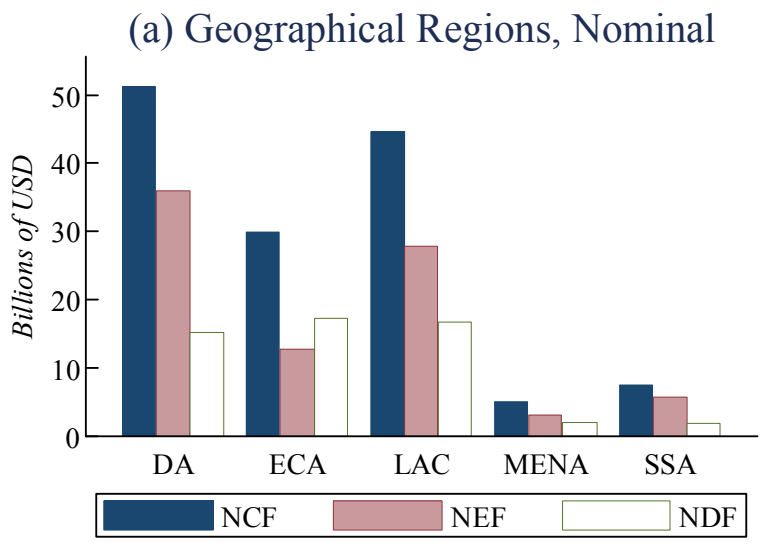

(c) Income Groups, Nominal

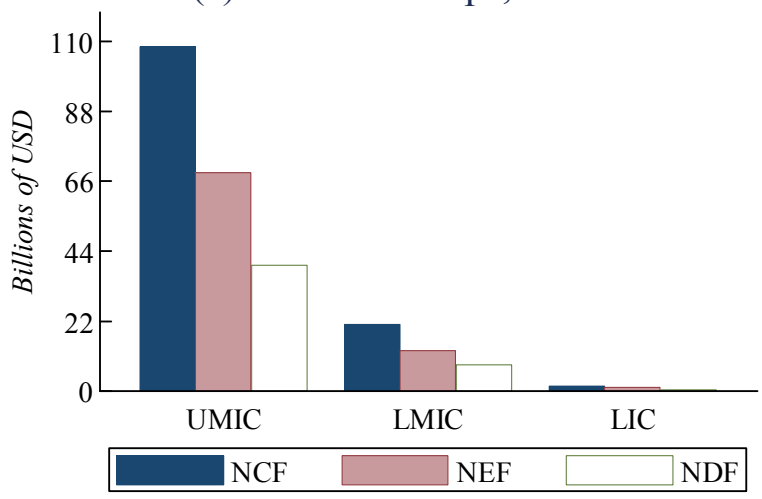

(b) Geographical Regions, Scaled

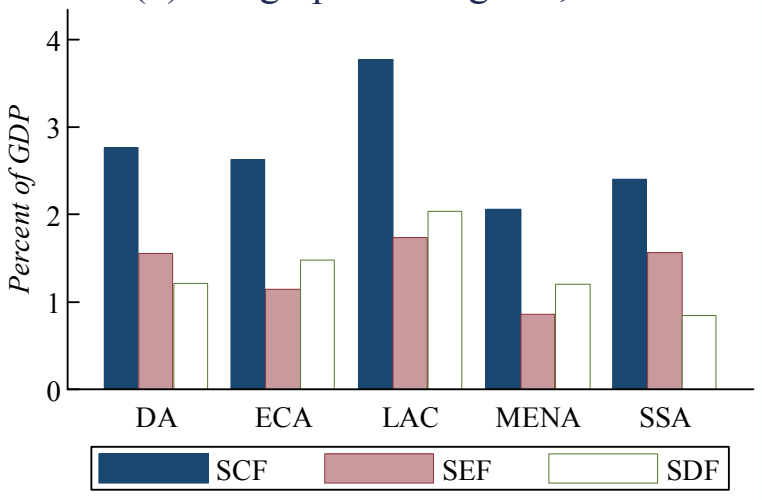

(d) Income Groups, Scaled

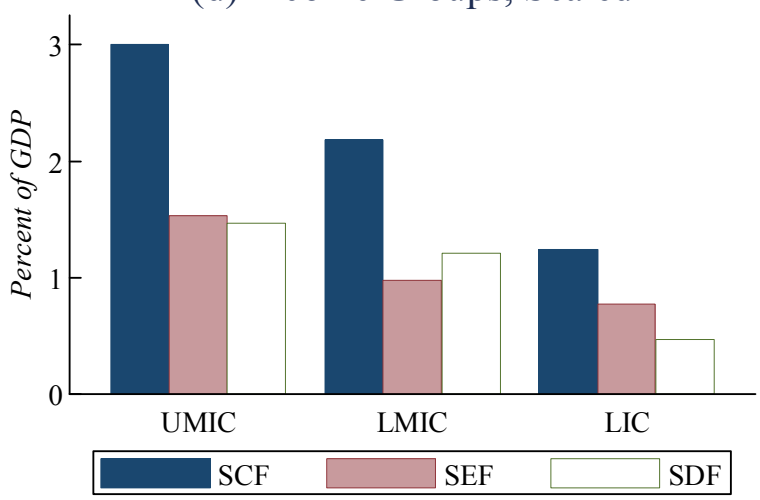

Sources: World Bank, World Development Indicators, Global Development Finance.

Notes: Geographical regions are Developing Asia (DA), Europe and Central Asia (ECA), Latin America and Caribbean (LAC), Middle East and North Africa (MENA), and Sub-Saharan Africa (SSA). Income groups refer to the World Bank's classification of countries according to the level of 2009 GNI per capita, calculated using the World Bank Atlas method. From those mutually exclusive groups; included are upper middle income countries (UMIC) which are also known as emerging economies, lower middle income countries (LMIC) and low income countries (LIC). Capital flow component bars indicate the simple arithmetic averages for the corresponding region or income group. See also notes to Figure 2. 
Table 2: Growth and Cyclicality of Total Capital Flows in Comparative Perspective

\begin{tabular}{|c|c|c|c|c|c|c|c|c|c|}
\hline & \multirow{2}{*}{ ADC } & \multicolumn{5}{|c|}{ Geographical Regions } & \multicolumn{3}{|c|}{ Income Groups } \\
\hline & & DA & ECA & LAC & MENA & SSA & UMIC & LMIC & LIC \\
\hline \multicolumn{10}{|c|}{ (a) Average and Median Annual Growths (Percent) } \\
\hline \multicolumn{10}{|c|}{ Means } \\
\hline$R C F$ & 12.58 & 21.68 & 174.14 & 24.51 & 945.40 & 30.11 & 17.12 & 69.22 & 220.01 \\
\hline$R E F$ & 14.34 & 19.30 & 55.74 & 15.58 & 28.56 & 90.44 & 21.47 & 18.87 & 86.17 \\
\hline$R D F$ & 40.88 & 35.97 & 67.95 & 170.00 & -8.23 & 42.35 & 178.85 & 37.91 & -64.20 \\
\hline$G D P$ & 5.42 & 4.34 & 2.39 & 3.89 & 4.83 & 2.57 & 4.12 & 3.42 & 0.84 \\
\hline$R E S$ & 13.28 & 11.99 & 8594.84 & 8.41 & 12.72 & 9.07 & 9.36 & 9.96 & 4.80 \\
\hline$T E D$ & 6.07 & 6.13 & 10.84 & 4.45 & 5.74 & 5.00 & 6.62 & 4.54 & 5.38 \\
\hline \multicolumn{10}{|c|}{ Medians } \\
\hline$R C F$ & 15.03 & 18.75 & 30.02 & 14.78 & 9.20 & 7.47 & 12.48 & 11.88 & -6.09 \\
\hline$R E F$ & 7.63 & 11.68 & 18.27 & 14.36 & 0.54 & 7.77 & 10.50 & 20.22 & 6.45 \\
\hline$R D F$ & 9.36 & 14.93 & 35.12 & -0.50 & -7.31 & 7.98 & 7.65 & 11.00 & -11.37 \\
\hline$G D P$ & 3.98 & 3.38 & 3.73 & 5.33 & 4.57 & 1.15 & 3.33 & 3.56 & 1.14 \\
\hline RES & 9.96 & 9.92 & 20.66 & 12.05 & 13.18 & 6.99 & 9.56 & 8.52 & 3.99 \\
\hline$T E D$ & 6.50 & 6.57 & 7.28 & 3.94 & 3.06 & 3.94 & 6.10 & 4.11 & 4.49 \\
\hline \multicolumn{10}{|c|}{ (b) Correlations with Real GDP Growth (Coefficient) } \\
\hline$R C F$ & $\begin{array}{r}0.18 \\
(0.30)\end{array}$ & $\begin{array}{r}0.27 \\
(0.11)\end{array}$ & $\begin{array}{r}0.15 \\
(0.46)\end{array}$ & $\begin{array}{r}0.19 \\
(0.27)\end{array}$ & $\begin{array}{r}-0.06 \\
(0.73)\end{array}$ & $\begin{array}{r}0.27 \\
(0.11)\end{array}$ & $\begin{array}{r}0.37 \\
(0.02)\end{array}$ & $\begin{array}{r}0.22 \\
(0.20)\end{array}$ & $\begin{array}{r}0.07 \\
(0.69)\end{array}$ \\
\hline$R E F$ & $\begin{array}{r}0.06 \\
(0.74)\end{array}$ & $\begin{array}{r}0.24 \\
(0.16)\end{array}$ & $\begin{array}{r}-0.01 \\
(0.95)\end{array}$ & $\begin{array}{r}0.42 \\
(0.01)\end{array}$ & $\begin{array}{r}0.15 \\
(0.37)\end{array}$ & $\begin{array}{r}0.16 \\
(0.36)\end{array}$ & $\begin{array}{r}0.46 \\
(0.00)\end{array}$ & $\begin{array}{r}-0.04 \\
(0.82)\end{array}$ & $\begin{array}{r}0.01 \\
(0.94)\end{array}$ \\
\hline$R D F$ & $\begin{array}{r}0.01 \\
(0.94)\end{array}$ & $\begin{array}{r}0.34 \\
(0.04)\end{array}$ & $\begin{array}{r}-0.24 \\
(0.23)\end{array}$ & $\begin{array}{r}0.35 \\
(0.04)\end{array}$ & $\begin{array}{r}-0.07 \\
(0.68)\end{array}$ & $\begin{array}{r}0.25 \\
(0.15)\end{array}$ & $\begin{array}{r}-0.13 \\
(0.45)\end{array}$ & $\begin{array}{r}0.35 \\
(0.04)\end{array}$ & $\begin{array}{r}0.06 \\
(0.74)\end{array}$ \\
\hline
\end{tabular}

Sources: World Bank, World Development Indicators, Global Development Finance.

Notes: Compound growth rates are computed over 1971-2006 for the variables that are expressed in real terms (constant 2005 US dollars). An $R$ in front of the acronyms of capital flow aggregates signifies this reality. ADC denotes all developing countries, RES stands for total international reserves that comprise holdings of monetary gold, special drawing rights, reserves of IMF members held by the IMF and holdings of foreign exchange under the control of monetary authorities and TED refers to total external debt outstanding and disbursed. TED is essentially a stock variable that covers the accumulated sum of public, publicly guaranteed, and private nonguaranteed long-term debt, use of IMF credit and short-term debt. The correlation between annual percentage changes in a flow aggregate and in the real GDP measures the cyclicality of that aggregate. Associated significance levels ( $p$-values) are in parentheses. See notes to Figure 3. 
Table 3: Equity Flows to Developing World by Sub-periods, Billions of USD

\begin{tabular}{|c|c|c|c|c|c|c|c|}
\hline Region and Component & $1970-74$ & 1975-79 & 1980-84 & 1985-89 & $1990-94$ & 1995-99 & 2000-06 \\
\hline \multicolumn{8}{|l|}{ All Developing Countries } \\
\hline Total Equity Inflows & $\begin{array}{l}3.22 \\
(0.5)\end{array}$ & $\begin{array}{r}6.03 \\
(0.5)\end{array}$ & $\begin{array}{r}11.24 \\
(0.3)\end{array}$ & $\begin{array}{r}15.72 \\
(0.4)\end{array}$ & $\begin{array}{r}66.82 \\
(1.6)\end{array}$ & $\begin{array}{r}161.92 \\
(2.8)\end{array}$ & $\begin{array}{r}261.91 \\
(3.1)\end{array}$ \\
\hline Direct Equity & $\begin{array}{r}3.22 \\
(0.5)\end{array}$ & $\begin{array}{c}6.01 \\
(0.5)\end{array}$ & $\begin{array}{r}11.14 \\
(0.3)\end{array}$ & $\begin{array}{r}15.26 \\
(0.4)\end{array}$ & $\begin{array}{r}51.14 \\
(1.2)\end{array}$ & $\begin{array}{r}144.72 \\
(2.5)\end{array}$ & $\begin{array}{r}224.72 \\
(2.7)\end{array}$ \\
\hline Portfolio Equity & $\begin{array}{r}0.004 \\
(0.0)\end{array}$ & $\begin{array}{c}0.02 \\
(0.0)\end{array}$ & $\begin{array}{r}0.10 \\
(0.0)\end{array}$ & $\begin{array}{r}0.46 \\
(0.0)\end{array}$ & $\begin{array}{r}15.68 \\
(0.4)\end{array}$ & $\begin{array}{r}17.21 \\
(0.3)\end{array}$ & $\begin{array}{r}37.19 \\
(0.4)\end{array}$ \\
\hline \multicolumn{8}{|l|}{ Developing Asia } \\
\hline Total Equity Inflows & $\begin{array}{r}0.35 \\
(0.1)\end{array}$ & $\begin{array}{l}0.72 \\
(0.2)\end{array}$ & $\begin{array}{l}2.44 \\
(0.4)\end{array}$ & $\begin{array}{r}6.00 \\
(0.7)\end{array}$ & $\begin{array}{r}29.99 \\
(2.3)\end{array}$ & $\begin{array}{r}63.92 \\
(3.2)\end{array}$ & $\begin{array}{r}116.33 \\
(3.3)\end{array}$ \\
\hline Direct Equity & $\begin{array}{c}0.35 \\
(0.1)\end{array}$ & $\begin{array}{r}0.72 \\
(0.2)\end{array}$ & $\begin{array}{l}2.41 \\
(0.4)\end{array}$ & $\begin{array}{c}5.49 \\
(0.6)\end{array}$ & $\begin{array}{r}26.80 \\
(2.1)\end{array}$ & $\begin{array}{r}59.63 \\
(3.0)\end{array}$ & $\begin{array}{r}91.74 \\
(2.7)\end{array}$ \\
\hline Portfolio Equity & $\begin{array}{r}\mathrm{n} / \mathrm{a} \\
(\mathrm{n} / \mathrm{a})\end{array}$ & $\begin{array}{r}0.002 \\
(0.0)\end{array}$ & $\begin{array}{c}0.03 \\
(0.0)\end{array}$ & $\begin{array}{r}0.51 \\
(0.1)\end{array}$ & $\begin{array}{r}3.19 \\
(0.2)\end{array}$ & $\begin{array}{l}4.29 \\
(0.2)\end{array}$ & $\begin{array}{r}24.59 \\
(0.7)\end{array}$ \\
\hline \multicolumn{8}{|l|}{ Europe and Central Asia } \\
\hline Total Equity Inflows & $\begin{array}{l}0.14 \\
(\mathrm{n} / \mathrm{a})\end{array}$ & $\begin{array}{l}0.25 \\
(\mathrm{n} / \mathrm{a})\end{array}$ & $\begin{array}{r}0.52 \\
(0.04)\end{array}$ & $\begin{array}{r}1.02 \\
(0.1)\end{array}$ & $\begin{array}{r}5.40 \\
(0.7)\end{array}$ & $\begin{array}{r}17.56 \\
(1.7)\end{array}$ & $\begin{array}{r}49.43 \\
(2.6)\end{array}$ \\
\hline Direct Equity & $\begin{array}{l}0.14 \\
(\mathrm{n} / \mathrm{a})\end{array}$ & $\begin{array}{l}0.25 \\
(\mathrm{n} / \mathrm{a})\end{array}$ & $\begin{array}{r}0.52 \\
(0.04)\end{array}$ & $\begin{array}{r}1.02 \\
(0.1)\end{array}$ & $\begin{array}{r}4.95 \\
(0.6)\end{array}$ & $\begin{array}{r}15.81 \\
(1.5)\end{array}$ & $\begin{array}{r}46.36 \\
(2.5)\end{array}$ \\
\hline Portfolio Equity & $\begin{array}{r}\mathrm{n} / \mathrm{a} \\
(\mathrm{n} / \mathrm{a})\end{array}$ & $\begin{array}{r}\mathrm{n} / \mathrm{a} \\
(\mathrm{n} / \mathrm{a})\end{array}$ & $\begin{array}{r}\mathrm{n} / \mathrm{a} \\
(\mathrm{n} / \mathrm{a})\end{array}$ & $\begin{array}{r}0.02 \\
(0.0)\end{array}$ & $\begin{array}{r}0.44 \\
(0.1)\end{array}$ & $\begin{array}{r}1.75 \\
(0.2)\end{array}$ & $\begin{array}{l}3.06 \\
(0.1)\end{array}$ \\
\hline \multicolumn{8}{|c|}{ Latin America and Caribbean } \\
\hline Total Equity Inflows & $\begin{array}{r}1.50 \\
(0.7)\end{array}$ & $\begin{array}{l}3.34 \\
(0.7)\end{array}$ & $\begin{array}{c}6.13 \\
(0.8)\end{array}$ & $\begin{array}{r}6.07 \\
(0.8)\end{array}$ & $\begin{array}{r}27.44 \\
(2.0)\end{array}$ & $\begin{array}{r}65.35 \\
(3.4)\end{array}$ & $\begin{array}{r}68.90 \\
(3.2)\end{array}$ \\
\hline Direct Equity & $\begin{array}{r}1.50 \\
(0.7)\end{array}$ & $\begin{array}{l}3.34 \\
(0.7)\end{array}$ & $\begin{array}{r}6.13 \\
(0.8)\end{array}$ & $\begin{array}{r}5.92 \\
(0.7)\end{array}$ & $\begin{array}{r}15.44 \\
(1.1)\end{array}$ & $\begin{array}{r}60.19 \\
(3.1)\end{array}$ & $\begin{array}{r}64.61 \\
(3.0)\end{array}$ \\
\hline Portfolio Equity & $\begin{array}{r}\mathrm{n} / \mathrm{a} \\
(\mathrm{n} / \mathrm{a})\end{array}$ & $\begin{array}{c}0.00 \\
(0.0)\end{array}$ & $\begin{array}{r}0.003 \\
(0.0)\end{array}$ & $\begin{array}{r}0.15 \\
(0.02)\end{array}$ & $\begin{array}{r}12.00 \\
(0.9)\end{array}$ & $\begin{array}{l}5.16 \\
(0.3)\end{array}$ & $\begin{array}{r}4.28 \\
(0.2)\end{array}$ \\
\hline \multicolumn{8}{|c|}{ Middle East and North Africa } \\
\hline Total Equity Inflows & $\begin{array}{r}0.37 \\
(0.7)\end{array}$ & $\begin{array}{c}0.95 \\
(0.7)\end{array}$ & $\begin{array}{l}1.07 \\
(0.5)\end{array}$ & $\begin{array}{r}1.34 \\
(0.5)\end{array}$ & $\begin{array}{r}1.91 \\
(0.7)\end{array}$ & $\begin{array}{l}2.75 \\
(0.7)\end{array}$ & $\begin{array}{r}10.35 \\
(1.8)\end{array}$ \\
\hline Direct Equity & $\begin{array}{r}0.37 \\
(0.7)\end{array}$ & $\begin{array}{r}0.94 \\
(0.7)\end{array}$ & $\begin{array}{l}1.00 \\
(0.4)\end{array}$ & $\begin{array}{r}1.32 \\
(0.5)\end{array}$ & $\begin{array}{r}1.84 \\
(0.7)\end{array}$ & $\begin{array}{l}2.47 \\
(0.7)\end{array}$ & $\begin{array}{r}9.77 \\
(1.7)\end{array}$ \\
\hline Portfolio Equity & $\begin{array}{r}\mathrm{n} / \mathrm{a} \\
(\mathrm{n} / \mathrm{a})\end{array}$ & $\begin{array}{r}0.001 \\
(0.0)\end{array}$ & $\begin{array}{r}0.07 \\
(0.03)\end{array}$ & $\begin{array}{r}0.02 \\
(0.01)\end{array}$ & $\begin{array}{r}0.07 \\
(0.03)\end{array}$ & $\begin{array}{r}0.28 \\
(0.1)\end{array}$ & $\begin{array}{c}0.58 \\
(0.1)\end{array}$ \\
\hline \multicolumn{8}{|l|}{ Sub-Saharan Africa } \\
\hline Total Equity Inflows & $\begin{array}{c}0.85 \\
(1.0)\end{array}$ & $\begin{array}{c}0.78 \\
(0.5)\end{array}$ & $\begin{array}{l}1.09 \\
(0.4)\end{array}$ & $\begin{array}{c}1.28 \\
(0.5)\end{array}$ & $\begin{array}{r}2.07 \\
(0.7)\end{array}$ & $\begin{array}{r}12.34 \\
(3.7)\end{array}$ & $\begin{array}{r}16.91 \\
(3.4)\end{array}$ \\
\hline Direct Equity & $\begin{array}{c}0.85 \\
(1.0)\end{array}$ & $\begin{array}{c}0.76 \\
(0.5)\end{array}$ & $\begin{array}{c}1.08 \\
(0.4)\end{array}$ & $\begin{array}{r}1.52 \\
(0.6)\end{array}$ & $\begin{array}{c}2.11 \\
(0.7)\end{array}$ & $\begin{array}{l}6.61 \\
(2.0)\end{array}$ & $\begin{array}{r}12.23 \\
(2.6)\end{array}$ \\
\hline Portfolio Equity & $\begin{array}{r}0.004 \\
(0.0)\end{array}$ & $\begin{array}{r}0.02 \\
(0.01)\end{array}$ & $\begin{array}{r}0.003 \\
(0.0)\end{array}$ & $\begin{array}{l}-0.23 \\
(-0.1)\end{array}$ & $\begin{array}{r}-0.04 \\
(-0.01)\end{array}$ & $\begin{array}{l}5.72 \\
(1.7)\end{array}$ & $\begin{array}{l}4.68 \\
(0.8)\end{array}$ \\
\hline
\end{tabular}

Sources: World Bank, World Development Indicators, Global Development Finance.

Notes: See notes to Table 1. 
Figure 4: Net Equity Flows to Developing World by Regions, 1970-2006

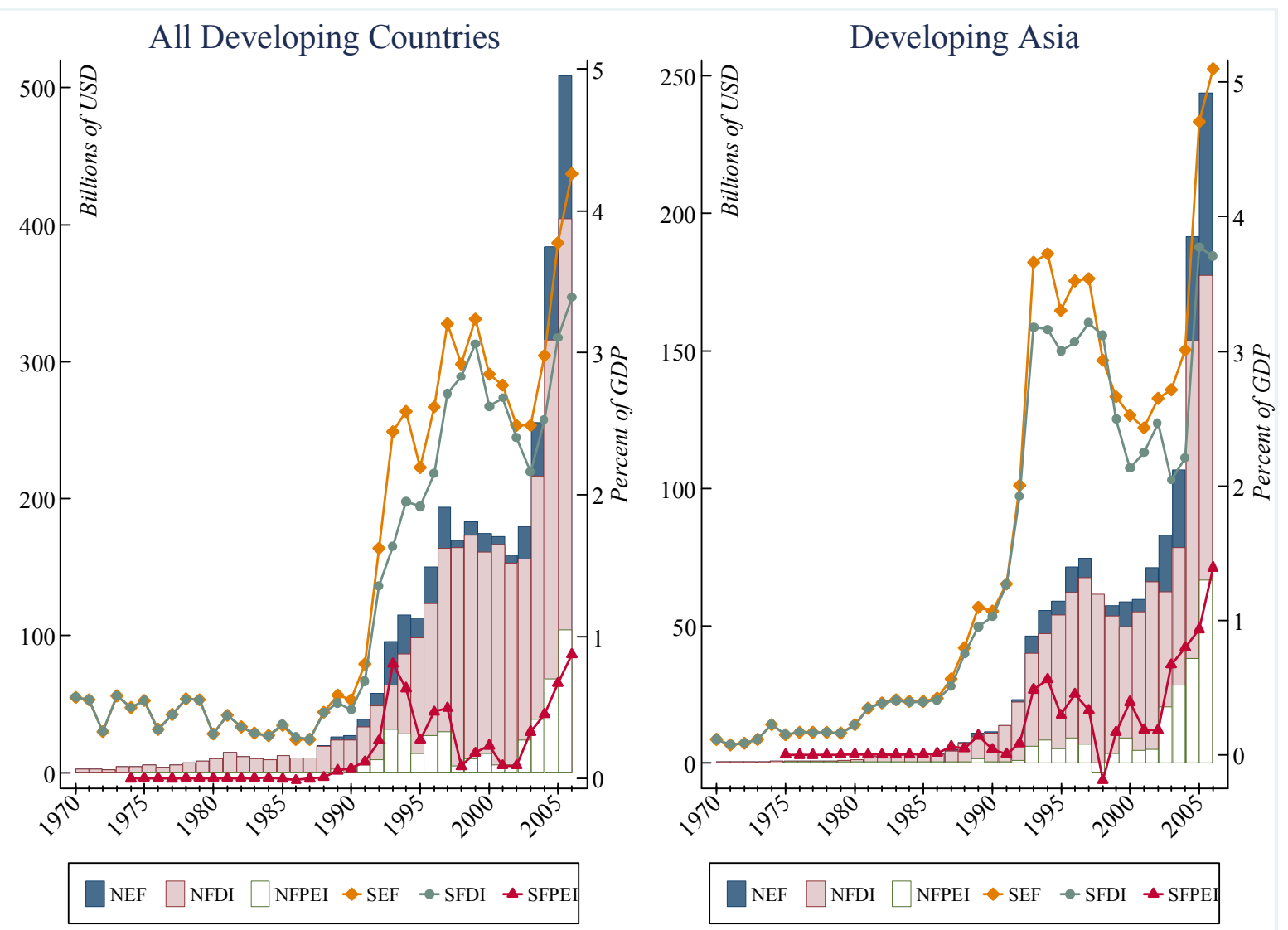

Europe and Central Asia
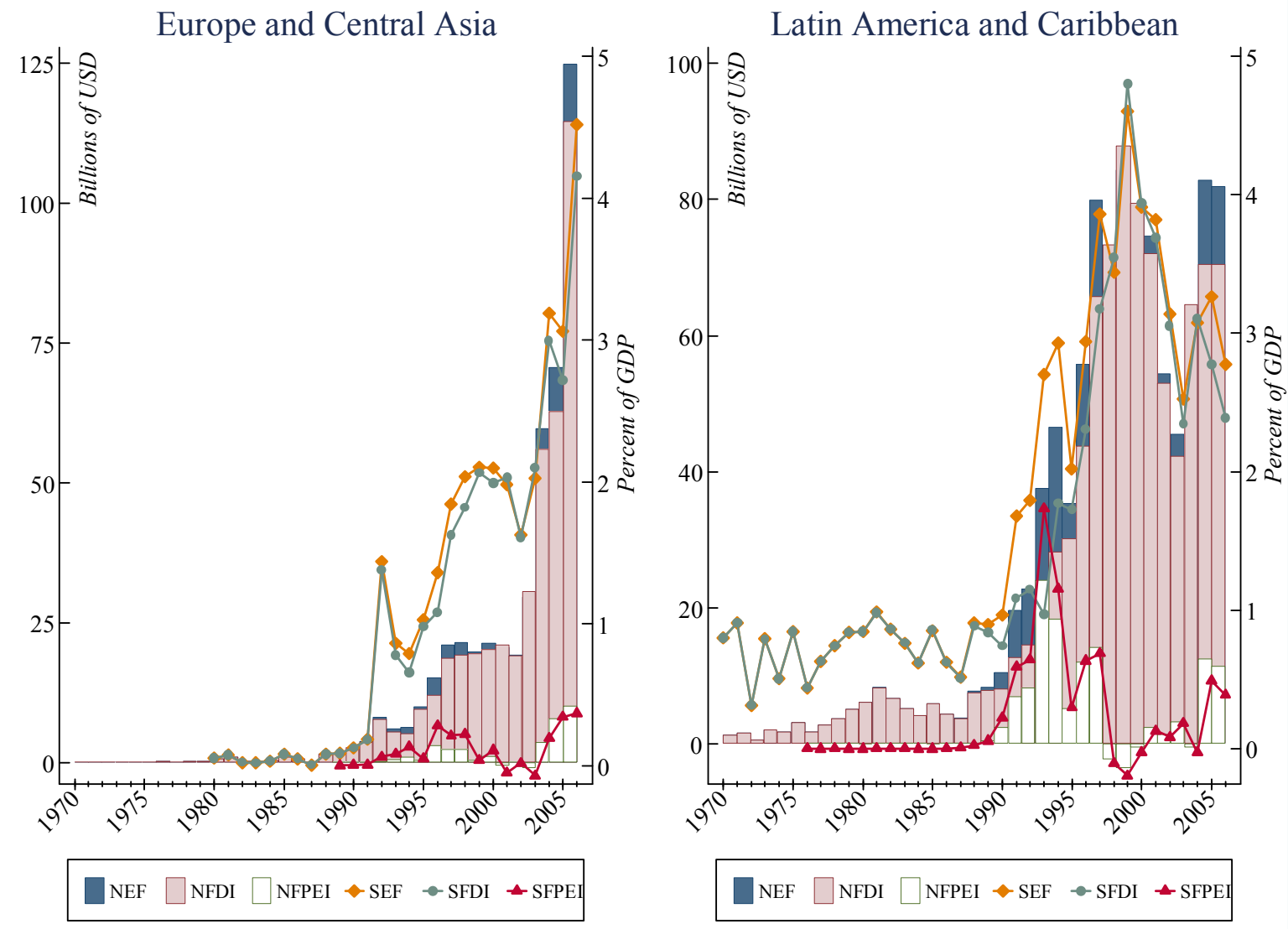

(continued on next page) 
Figure 4 (continued)

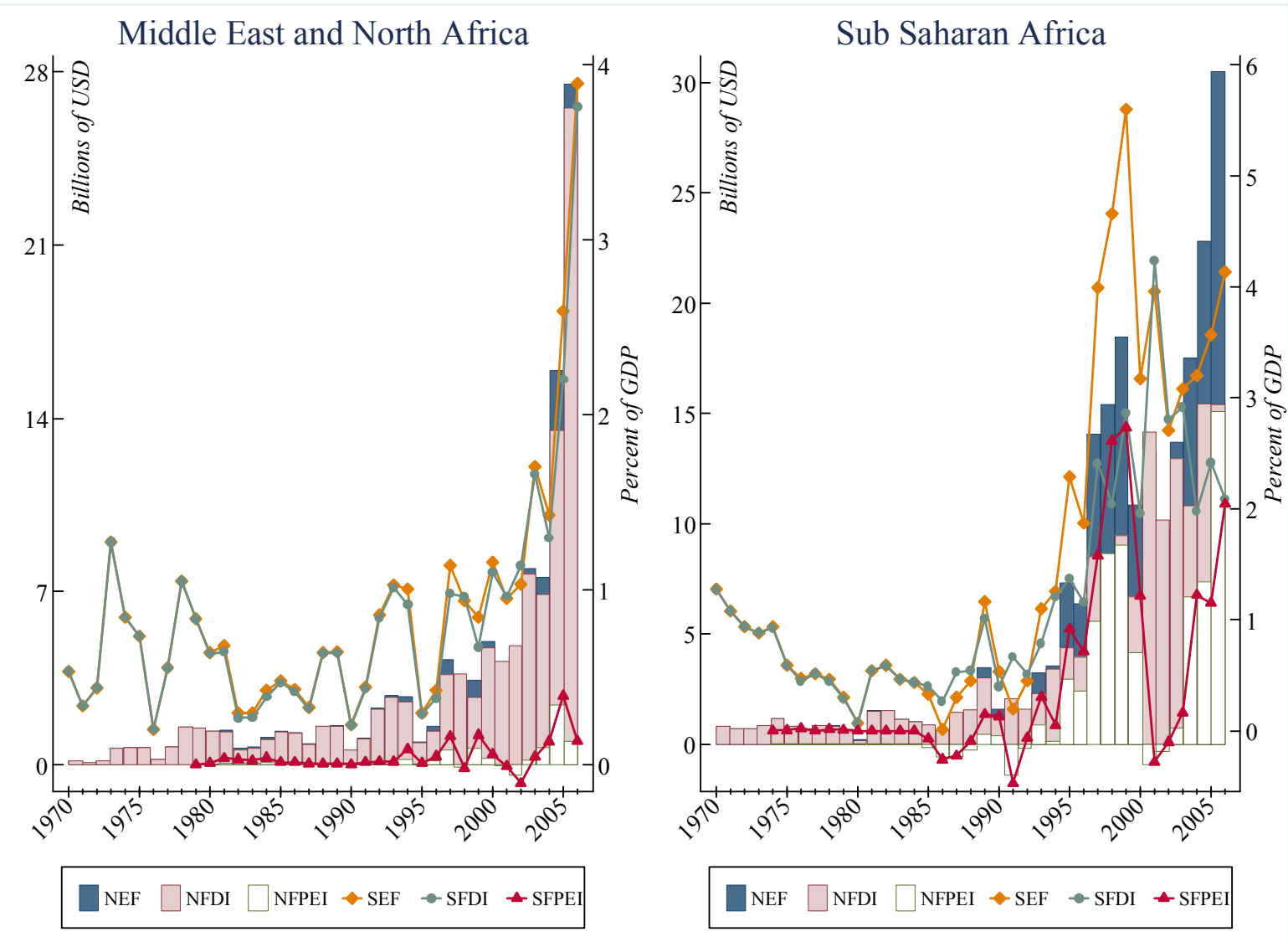

Sources: World Bank, World Development Indicators, Global Development Finance.

Notes: FDI refers to foreign direct investment and FPEI stands for foreign portfolio equity investment. The true NEF for a year is the vertical sum of all the bars within that year, while the true NFDI is what remains from the white bar (NFPEI) in a certain year. Light shaded bars exhibit the amount of NFDI in excess of NFPEI when both have the same signs and they show the whole NFDI when the signs are opposite. See notes to Figure 2. 
Figure 5: Distribution of Equity Inflows by Geographical Regions and Income Groups

(a) Geographical Regions, Nominal

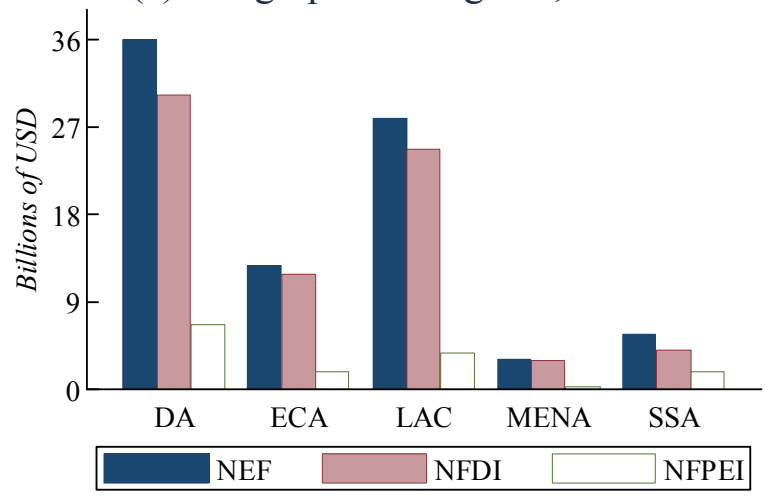

(c) Income Groups, Nominal

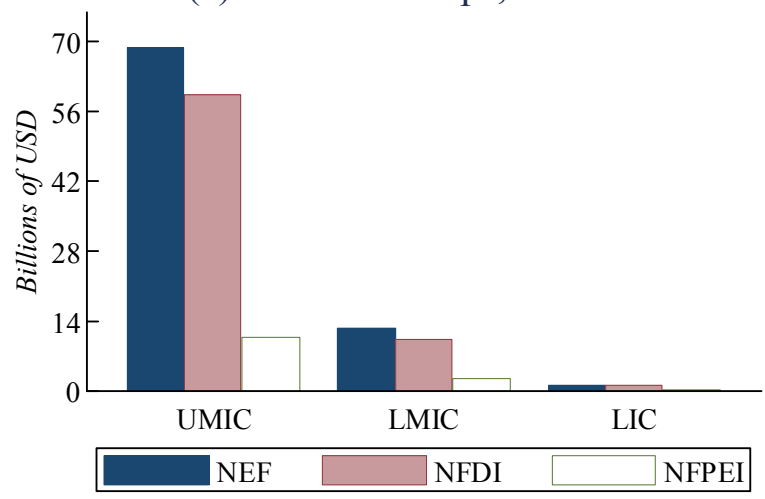

(b) Geographical Regions, Scaled

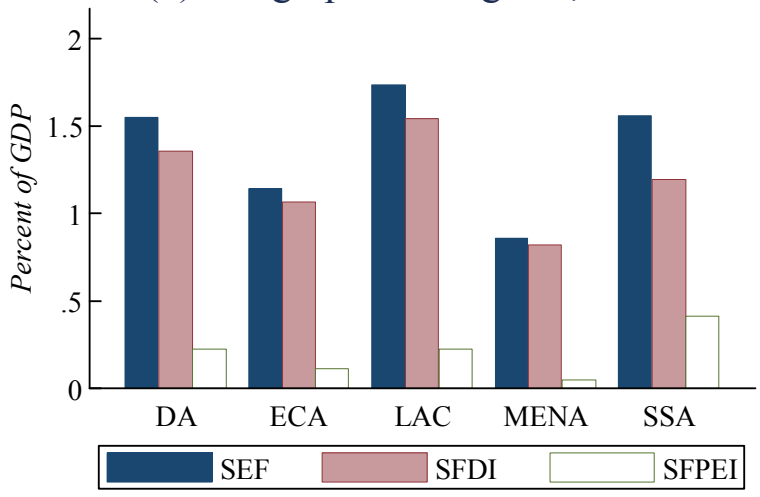

(d) Income Groups, Scaled

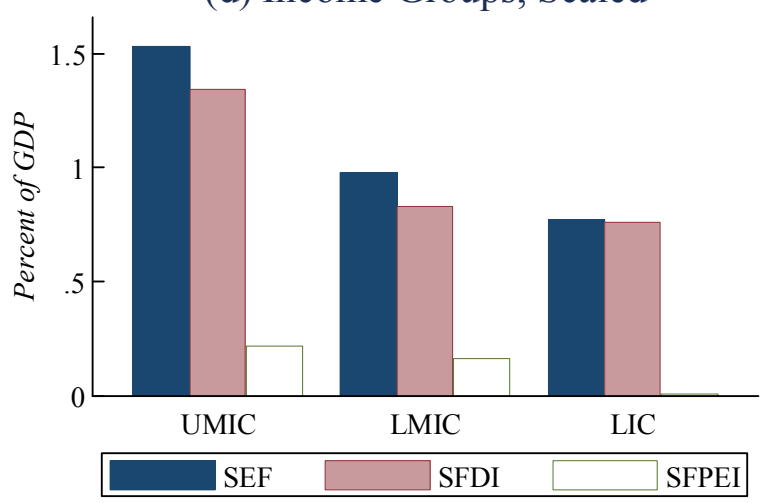

Sources: World Bank, World Development Indicators, Global Development Finance.

Notes: See notes to Figures 3 and 4. 
Table 4: Growth and Cyclicality of Equity Flows in Comparative Perspective

\begin{tabular}{|c|c|c|c|c|c|c|c|c|c|}
\hline & \multirow{2}{*}{ ADC } & \multicolumn{5}{|c|}{ Geographical Regions } & \multicolumn{3}{|c|}{ Income Groups } \\
\hline & & DA & ECA & LAC & MENA & SSA & UMIC & LMIC & LIC \\
\hline \multicolumn{10}{|c|}{ (a) Average and Median Annual Growths (Percent) } \\
\hline \multicolumn{10}{|l|}{ Means } \\
\hline$R E F$ & 14.34 & 19.30 & 55.74 & 15.58 & 28.56 & 90.44 & 21.47 & 18.87 & 86.17 \\
\hline$R F D I$ & 13.25 & 18.19 & 55.59 & 15.22 & 28.43 & 24.80 & 20.15 & 17.31 & 71.66 \\
\hline RFPEI & 587.63 & 377.06 & 75.53 & 112.79 & 140.21 & -73.7 & 146.53 & 865.43 & 1256.51 \\
\hline \multicolumn{10}{|c|}{ Medians } \\
\hline$R E F$ & 7.63 & 11.68 & 18.27 & 14.36 & 0.54 & 7.77 & 10.50 & 20.22 & 6.45 \\
\hline$R F D I$ & 7.30 & 10.63 & 16.38 & 5.58 & 3.83 & -4.54 & 10.37 & 16.96 & 8.90 \\
\hline RFPEI & 58.72 & 34.31 & 58.74 & 15.13 & 6.65 & 13.74 & 61.60 & 69.31 & 13.73 \\
\hline \multicolumn{10}{|c|}{ (b) Pairwise Correlations with Real GDP Growth } \\
\hline$R E F$ & $\begin{array}{r}0.06 \\
(0.74)\end{array}$ & $\begin{array}{r}0.24 \\
(0.16)\end{array}$ & $\begin{array}{r}-0.01 \\
(0.95)\end{array}$ & $\begin{array}{r}0.42 \\
(0.01)\end{array}$ & $\begin{array}{r}0.15 \\
(0.37)\end{array}$ & $\begin{array}{r}0.16 \\
(0.36)\end{array}$ & $\begin{array}{r}0.46 \\
(0.00)\end{array}$ & $\begin{array}{r}-0.04 \\
(0.82)\end{array}$ & $\begin{array}{r}0.01 \\
(0.94)\end{array}$ \\
\hline$R F D I$ & $\begin{array}{r}0.06 \\
(0.74)\end{array}$ & $\begin{array}{r}0.19 \\
(0.27)\end{array}$ & $\begin{array}{r}-0.02 \\
(0.94)\end{array}$ & $\begin{array}{r}0.43 \\
(0.01)\end{array}$ & $\begin{array}{r}0.15 \\
(0.38)\end{array}$ & $\begin{array}{r}-0.18 \\
(0.30)\end{array}$ & $\begin{array}{r}0.46 \\
(0.00)\end{array}$ & $\begin{array}{r}-0.07 \\
(0.68)\end{array}$ & $\begin{array}{r}0.02 \\
(0.90)\end{array}$ \\
\hline RFPEI & $\begin{array}{r}0.00 \\
(0.99)\end{array}$ & $\begin{array}{r}-0.24 \\
(0.19)\end{array}$ & $\begin{array}{r}-0.01 \\
(0.96)\end{array}$ & $\begin{array}{r}0.38 \\
(0.04)\end{array}$ & $\begin{array}{r}0.09 \\
(0.65)\end{array}$ & $\begin{array}{r}0.30 \\
(0.10)\end{array}$ & $\begin{array}{r}-0.04 \\
(0.82)\end{array}$ & $\begin{array}{r}-0.14 \\
(0.44)\end{array}$ & $\begin{array}{r}-0.27 \\
(0.14)\end{array}$ \\
\hline
\end{tabular}

Sources: World Bank, World Development Indicators, Global Development Finance.

Notes: See notes to Table 2. 
Figure 6: FDI Share of Gross Domestic Investment at the Periphery, 1970-2006

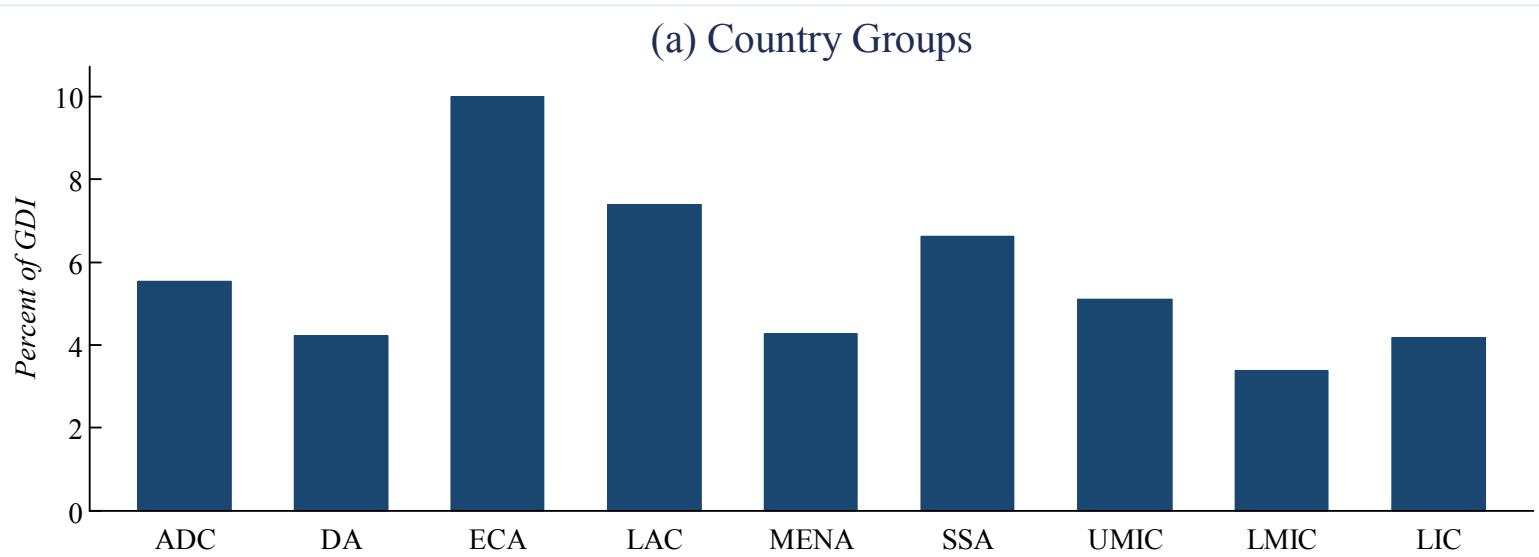

(b) 5-Year Periods

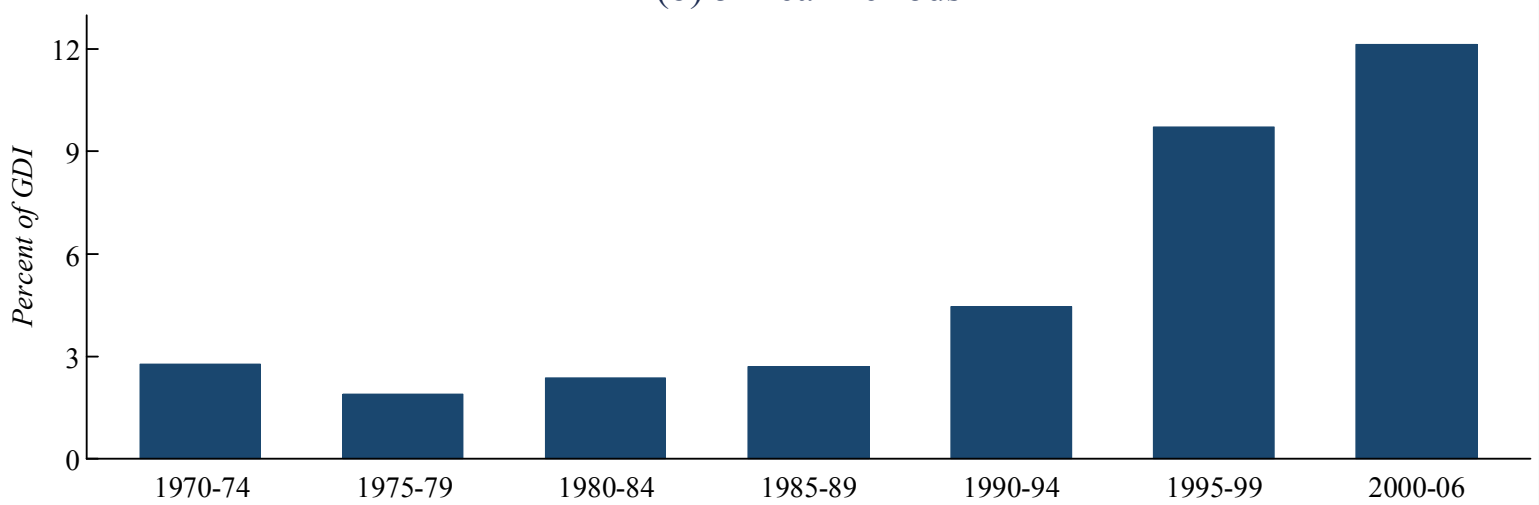

Sources: World Bank, World Development Indicators (WDI) and author's calculations.

Notes: Gross domestic investment (GDI), or gross capital formation as in WDI, consists of outlays on additions to the fixed assets of the economy plus net changes in the level of inventories. Fixed assets include land improvements (fences, ditches, drains and so on), plant, machinery and equipment purchases and the construction of roads, railways and the like, including schools, offices, hospitals, private residential dwellings and commercial and industrial buildings. Inventories are stocks of goods held by firms to meet temporary or unexpected fluctuations in production or sales and work in progress. According to the United Nations' (UN) System of National Accounts (SNA) in 1993, net acquisitions of valuables are also considered capital formation. Bars show arithmetic averages for the corresponding period or country group. See also notes to Figure 3. 
Figure 7: Foreign Participation in Stock Markets at the Periphery, 1985-2006

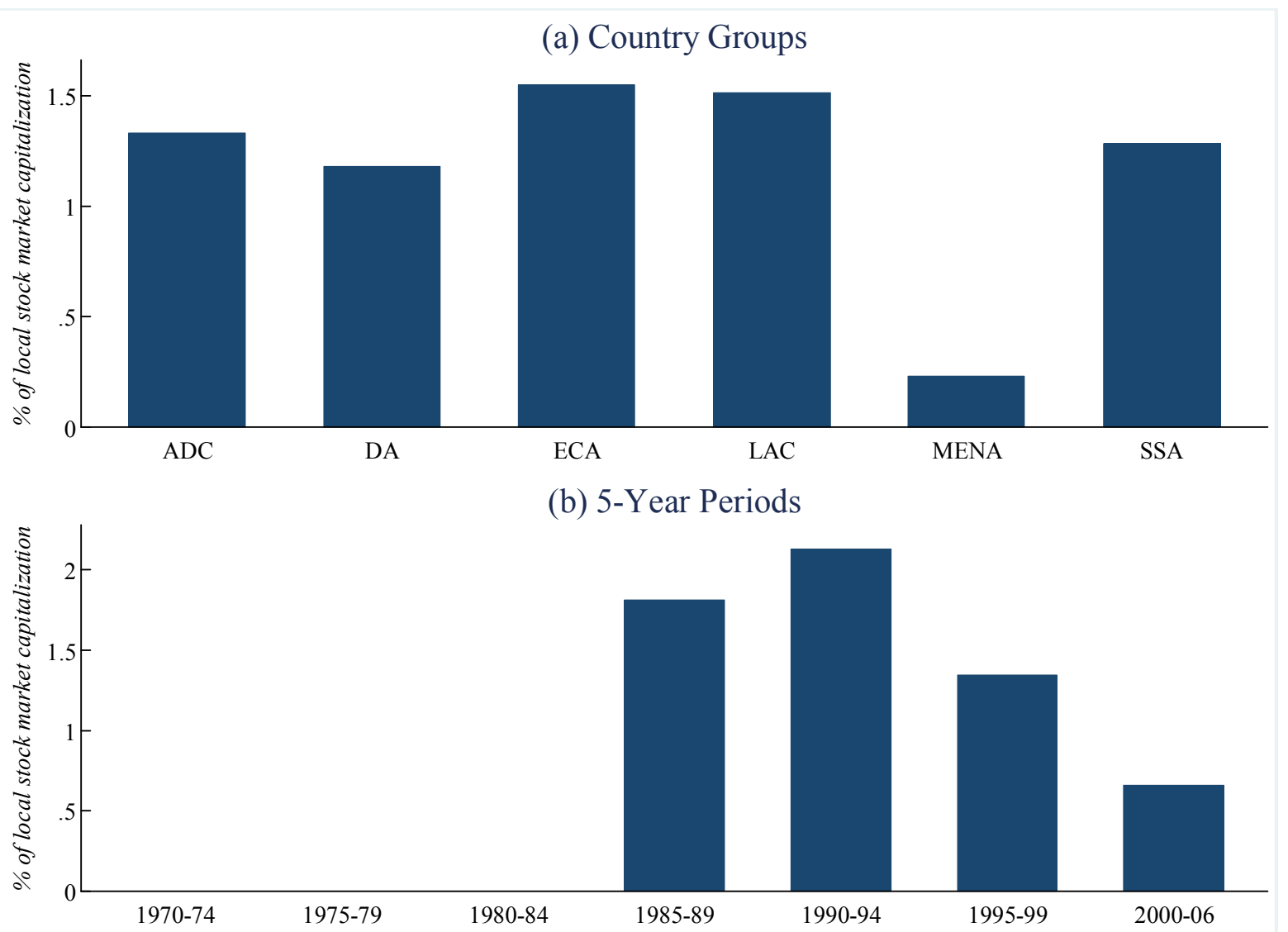

Sources: World Bank, World Development Indicators (WDI) and author's calculations.

Notes: Market capitalization (also known as market value) of domestically listed companies is the share price times the number of shares outstanding as of the yearend. Listed domestic companies are the domestically incorporated companies listed on the country's stock exchanges. Excluded are investment companies, mutual funds or other collective investment vehicles. The figure does not show the plots for income groups and some earlier sub-periods due to data unavailability. Bars demonstrate country group and period averages of FPEI that is expressed as percent of domestic stock market capitalization. See notes to Figure 6 as well. 
Table 5: Debt Flows to Developing World by Sub-periods, Billions of USD

\begin{tabular}{|c|c|c|c|c|c|c|c|}
\hline Region and Component & 1970-74 & 1975-79 & 1980-84 & 1985-89 & 1990-94 & 1995-99 & 2000-06 \\
\hline \multicolumn{8}{|l|}{ All Developing Countries } \\
\hline Total Debt Inflows & $\begin{array}{r}10.20 \\
(1.5)\end{array}$ & $\begin{array}{r}42.56 \\
(3.4)\end{array}$ & $\begin{array}{r}53.45 \\
(1.7)\end{array}$ & $\begin{array}{r}29.39 \\
(0.8)\end{array}$ & $\begin{array}{r}60.45 \\
(1.5)\end{array}$ & $\begin{array}{r}74.94 \\
(1.3)\end{array}$ & $\begin{array}{r}87.11 \\
(0.9)\end{array}$ \\
\hline Long-term Debt & $\begin{array}{c}8.52 \\
(1.3)\end{array}$ & $\begin{array}{r}31.35 \\
(2.5)\end{array}$ & $\begin{array}{r}46.71 \\
(1.5)\end{array}$ & $\begin{array}{r}21.50 \\
(0.6)\end{array}$ & $\begin{array}{r}38.06 \\
(0.9)\end{array}$ & $\begin{array}{r}64.41 \\
(1.1)\end{array}$ & $\begin{array}{r}40.85 \\
(0.4)\end{array}$ \\
\hline Short-term Debt & $\begin{array}{l}2.10 \\
(0.3)\end{array}$ & $\begin{array}{r}11.21 \\
(0.9)\end{array}$ & $\begin{array}{r}6.74 \\
(0.2)\end{array}$ & $\begin{array}{r}7.89 \\
(0.2)\end{array}$ & $\begin{array}{r}22.39 \\
(0.5)\end{array}$ & $\begin{array}{r}10.53 \\
(0.2)\end{array}$ & $\begin{array}{r}46.26 \\
(0.5)\end{array}$ \\
\hline \multicolumn{8}{|l|}{ Developing Asia } \\
\hline Total Debt Inflows & $\begin{array}{r}1.27 \\
(0.5)\end{array}$ & $\begin{array}{l}5.35 \\
(1.2)\end{array}$ & $\begin{array}{r}13.54 \\
(2.0)\end{array}$ & $\begin{array}{r}12.34 \\
(1.4)\end{array}$ & $\begin{array}{r}26.20 \\
(2.2)\end{array}$ & $\begin{array}{r}15.96 \\
(0.8)\end{array}$ & $\begin{array}{r}27.20 \\
(0.7)\end{array}$ \\
\hline Long-term Debt & $\begin{array}{c}1.00 \\
(0.4)\end{array}$ & $\begin{array}{l}3.57 \\
(0.8)\end{array}$ & $\begin{array}{r}10.09 \\
(1.5)\end{array}$ & $\begin{array}{l}9.97 \\
(1.1)\end{array}$ & $\begin{array}{r}16.77 \\
(1.4)\end{array}$ & $\begin{array}{r}17.28 \\
(0.9)\end{array}$ & $\begin{array}{l}-0.62 \\
(-0.1)\end{array}$ \\
\hline Short-term Debt & $\begin{array}{c}0.34 \\
(0.1)\end{array}$ & $\begin{array}{l}1.78 \\
(0.4)\end{array}$ & $\begin{array}{r}3.45 \\
(0.5)\end{array}$ & $\begin{array}{r}2.37 \\
(0.3)\end{array}$ & $\begin{array}{r}9.43 \\
(0.8)\end{array}$ & $\begin{array}{r}-1.32 \\
(-0.03)\end{array}$ & $\begin{array}{r}27.82 \\
(0.8)\end{array}$ \\
\hline \multicolumn{8}{|l|}{ Europe and Central Asia } \\
\hline Total Debt Inflows & $\begin{array}{l}0.87 \\
(\mathrm{n} / \mathrm{a})\end{array}$ & $\begin{array}{l}4.63 \\
(\mathrm{n} / \mathrm{a})\end{array}$ & $\begin{array}{c}5.94 \\
(0.5)\end{array}$ & $\begin{array}{r}6.17 \\
(0.4)\end{array}$ & $\begin{array}{r}6.90 \\
(1.1)\end{array}$ & $\begin{array}{r}20.43 \\
(1.9)\end{array}$ & $\begin{array}{r}59.07 \\
(3.0)\end{array}$ \\
\hline Long-term Debt & $\begin{array}{l}0.70 \\
(\mathrm{n} / \mathrm{a})\end{array}$ & $\begin{array}{l}3.92 \\
(\mathrm{n} / \mathrm{a})\end{array}$ & $\begin{array}{r}6.31 \\
(0.5)\end{array}$ & $\begin{array}{r}3.45 \\
(0.2)\end{array}$ & $\begin{array}{r}8.42 \\
(1.1)\end{array}$ & $\begin{array}{r}14.01 \\
(1.3)\end{array}$ & $\begin{array}{r}40.62 \\
(2.0)\end{array}$ \\
\hline Short-term Debt & $\begin{array}{l}0.21 \\
(\mathrm{n} / \mathrm{a})\end{array}$ & $\begin{array}{l}0.71 \\
(\mathrm{n} / \mathrm{a})\end{array}$ & $\begin{array}{r}-0.37 \\
(-0.03)\end{array}$ & $\begin{array}{c}2.72 \\
(0.2)\end{array}$ & $\begin{array}{r}-1.52 \\
(-0.04)\end{array}$ & $\begin{array}{c}6.42 \\
(0.6)\end{array}$ & $\begin{array}{r}18.45 \\
(1.0)\end{array}$ \\
\hline \multicolumn{8}{|c|}{ Latin America and Caribbean } \\
\hline Total Debt Inflows & $\begin{array}{c}6.71 \\
(2.7)\end{array}$ & $\begin{array}{r}23.70 \\
(4.9)\end{array}$ & $\begin{array}{r}25.47 \\
(3.2)\end{array}$ & $\begin{array}{c}3.68 \\
(0.5)\end{array}$ & $\begin{array}{r}23.70 \\
(1.8)\end{array}$ & $\begin{array}{r}39.92 \\
(2.1)\end{array}$ & $\begin{array}{r}0.51 \\
(-0.03)\end{array}$ \\
\hline Long-term Debt & $\begin{array}{l}5.72 \\
(2.3)\end{array}$ & $\begin{array}{r}16.77 \\
(3.5)\end{array}$ & $\begin{array}{r}22.87 \\
(3.0)\end{array}$ & $\begin{array}{r}3.29 \\
(0.5)\end{array}$ & $\begin{array}{r}11.94 \\
(0.9)\end{array}$ & $\begin{array}{r}37.52 \\
(1.9)\end{array}$ & $\begin{array}{c}2.39 \\
(0.1)\end{array}$ \\
\hline Short-term Debt & $\begin{array}{r}1.24 \\
(0.5)\end{array}$ & $\begin{array}{l}6.94 \\
(1.4)\end{array}$ & $\begin{array}{l}2.60 \\
(0.2)\end{array}$ & $\begin{array}{r}0.39 \\
(0.01)\end{array}$ & $\begin{array}{r}11.77 \\
(0.9)\end{array}$ & $\begin{array}{r}2.40 \\
(0.1)\end{array}$ & $\begin{array}{r}-1.87 \\
(-0.14)\end{array}$ \\
\hline \multicolumn{8}{|c|}{ Middle East and North Africa } \\
\hline Total Debt Inflows & $\begin{array}{r}0.56 \\
(1.2)\end{array}$ & $\begin{array}{l}5.15 \\
(3.8)\end{array}$ & $\begin{array}{l}3.16 \\
(1.4)\end{array}$ & $\begin{array}{r}3.53 \\
(1.3)\end{array}$ & $\begin{array}{l}3.06 \\
(1.2)\end{array}$ & $\begin{array}{l}-1.27 \\
(-0.3)\end{array}$ & $\begin{array}{r}0.43 \\
(0.2)\end{array}$ \\
\hline Long-term Debt & $\begin{array}{c}0.50 \\
(1.1)\end{array}$ & $\begin{array}{l}4.28 \\
(3.2)\end{array}$ & $\begin{array}{l}3.15 \\
(1.3)\end{array}$ & $\begin{array}{r}3.06 \\
(1.1)\end{array}$ & $\begin{array}{c}0.48 \\
(0.2)\end{array}$ & $\begin{array}{l}-2.72 \\
(-0.7)\end{array}$ & $\begin{array}{r}-0.49 \\
(0.02)\end{array}$ \\
\hline Short-term Debt & $\begin{array}{r}0.07 \\
(0.1)\end{array}$ & $\begin{array}{r}0.87 \\
(0.7)\end{array}$ & $\begin{array}{r}0.01 \\
(0.03)\end{array}$ & $\begin{array}{r}0.47 \\
(0.2)\end{array}$ & $\begin{array}{l}2.58 \\
(1.0)\end{array}$ & $\begin{array}{r}1.44 \\
(0.4)\end{array}$ & $\begin{array}{c}0.92 \\
(0.2)\end{array}$ \\
\hline \multicolumn{8}{|l|}{ Sub-Saharan Africa } \\
\hline Total Debt Inflows & $\begin{array}{r}0.80 \\
(0.9)\end{array}$ & $\begin{array}{l}3.73 \\
(2.1)\end{array}$ & $\begin{array}{l}5.34 \\
(2.1)\end{array}$ & $\begin{array}{r}3.67 \\
(1.4)\end{array}$ & $\begin{array}{c}0.58 \\
(0.2)\end{array}$ & $\begin{array}{r}-0.10 \\
(-0.03)\end{array}$ & $\begin{array}{c}-0.10 \\
(-0.3)\end{array}$ \\
\hline Long-term Debt & $\begin{array}{c}0.62 \\
(0.7)\end{array}$ & $\begin{array}{l}2.81 \\
(1.6)\end{array}$ & $\begin{array}{l}4.29 \\
(1.6)\end{array}$ & $\begin{array}{r}1.73 \\
(0.6)\end{array}$ & $\begin{array}{r}0.46 \\
(0.2)\end{array}$ & $\begin{array}{l}-1.69 \\
(-0.5)\end{array}$ & $\begin{array}{l}-1.05 \\
(-0.3)\end{array}$ \\
\hline Short-term Debt & $\begin{array}{c}0.23 \\
(0.3)\end{array}$ & $\begin{array}{c}0.92 \\
(0.5)\end{array}$ & $\begin{array}{l}1.05 \\
(0.4)\end{array}$ & $\begin{array}{c}1.94 \\
(0.8)\end{array}$ & $\begin{array}{r}0.13 \\
(0.03)\end{array}$ & $\begin{array}{r}1.59 \\
(0.5)\end{array}$ & $\begin{array}{c}0.95 \\
(0.0)\end{array}$ \\
\hline
\end{tabular}

Sources: World Bank, World Development Indicators, Global Development Finance.

Notes: See notes to Table 1. 
Figure 8: Net Debt Flows to Developing World by Regions, 1970-2006
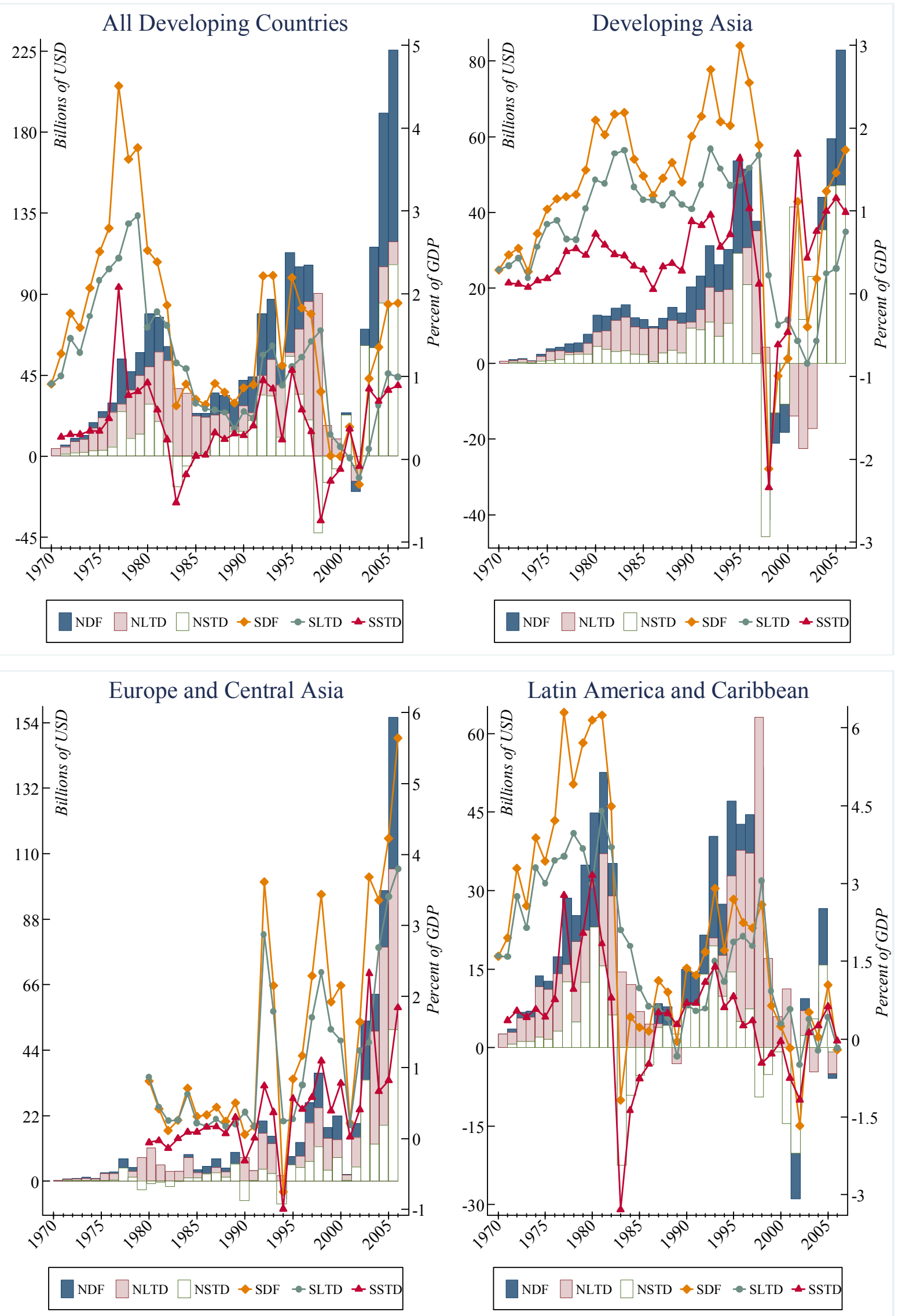

(continued on next page) 
Figure 8 (continued)

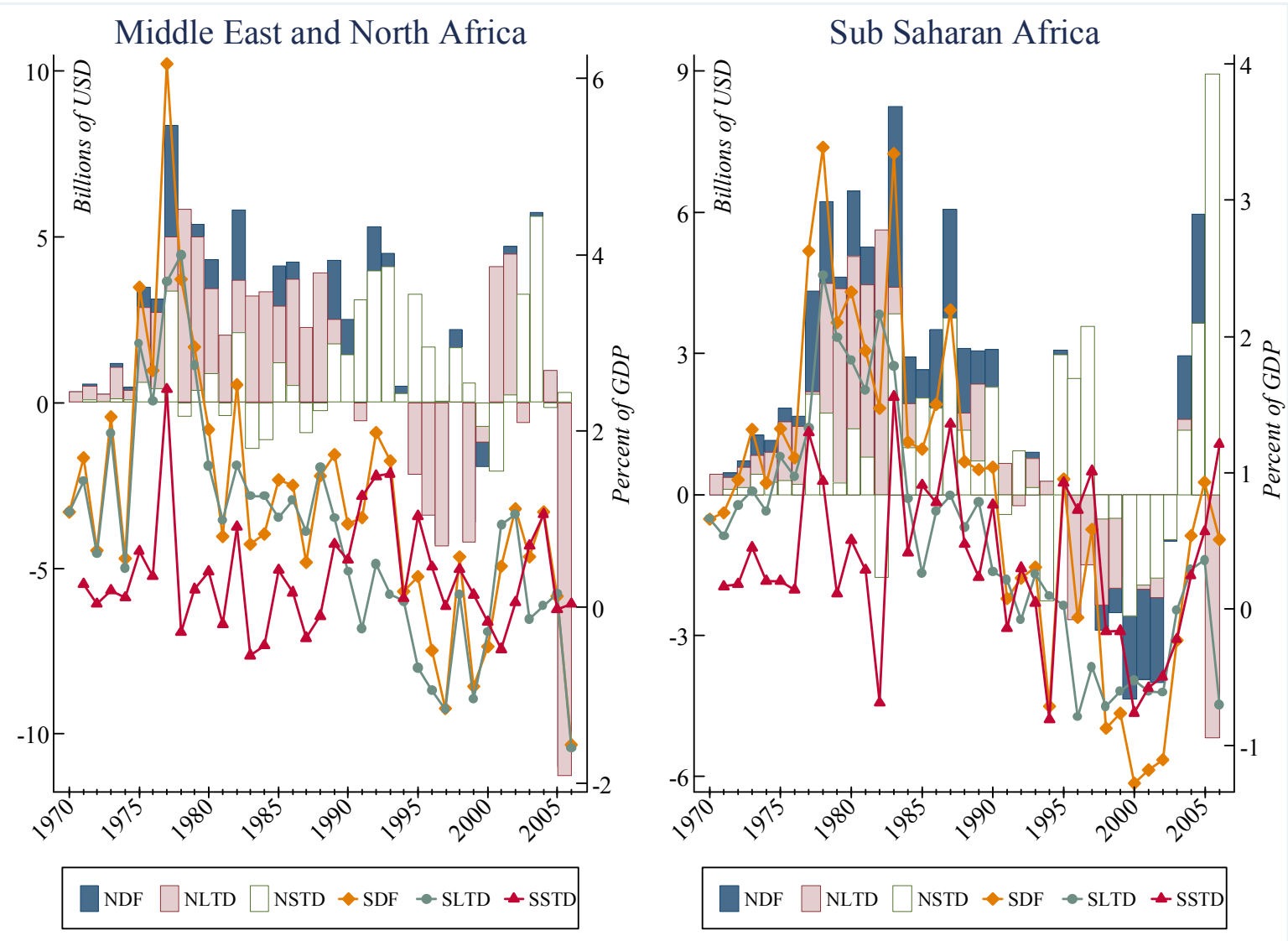

Sources: World Bank, World Development Indicators, Global Development Finance.

Notes: LTD refers to long-term debt and STD stands for short-term debt. The true NDF for a year is the vertical sum of all the bars within that year, while the true NLTD is what remains from the white bar (NSTD) in a certain year. Light shaded bars exhibit merely the amount of NLTD in excess of NSTD when both have the same signs and they show the whole NLTD when the signs are opposite. Also see notes to Figure 2. 
Figure 9: Distribution of Debt Inflows by Geographical Regions and Income Groups

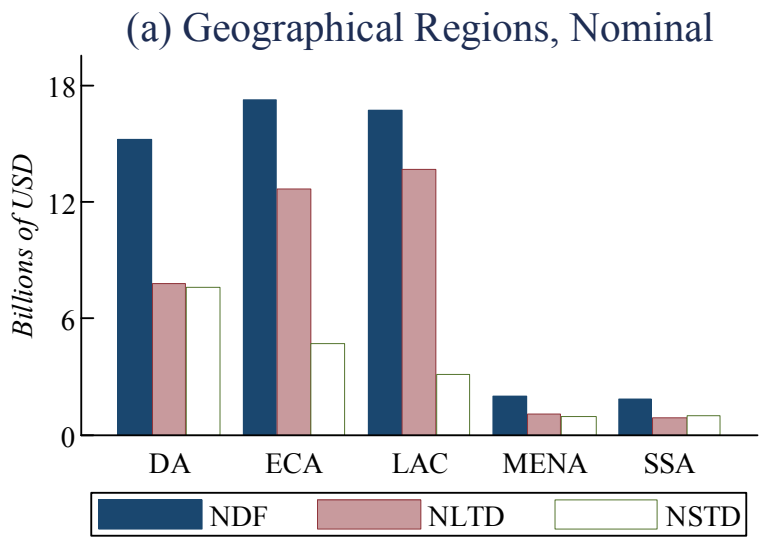

(c) Income Groups, Nominal

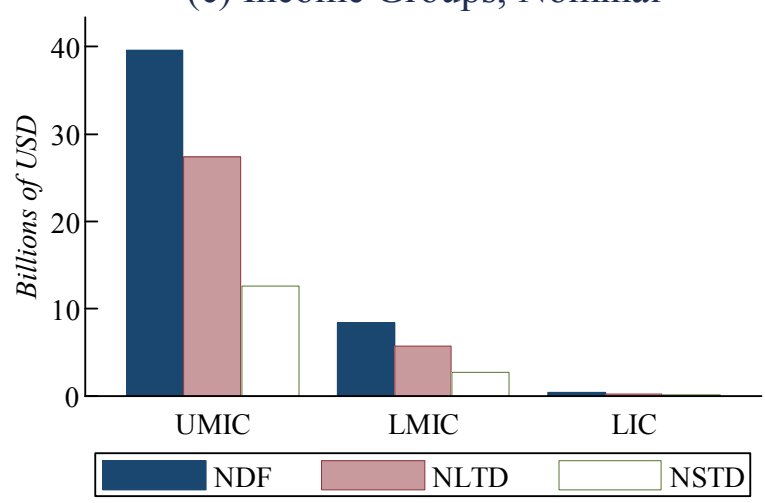

(b) Geographical Regions, Scaled

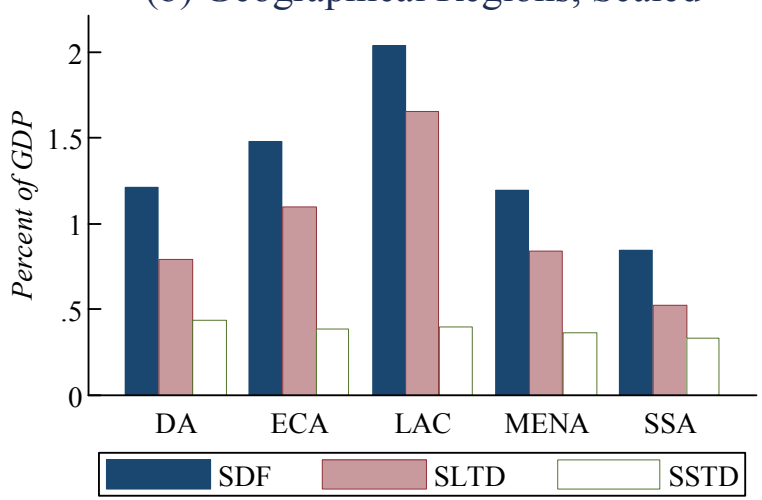

(d) Income Groups, Scaled

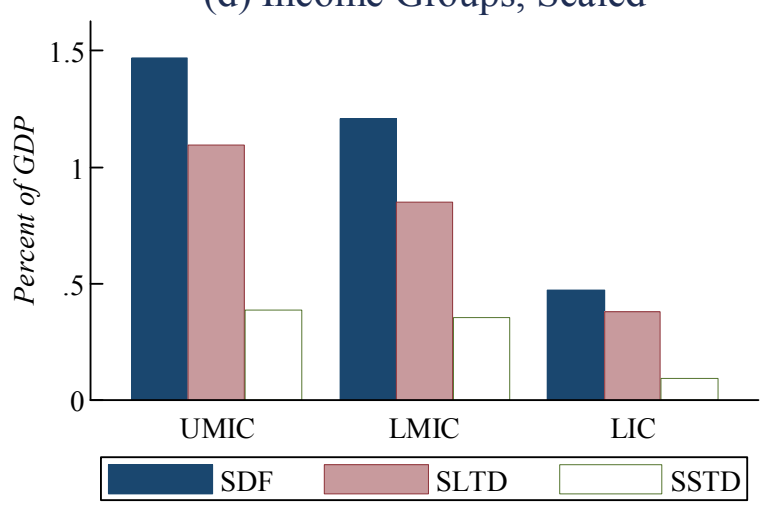

Sources: World Bank, World Development Indicators, Global Development Finance.

Notes: See notes to Figures 3 and 8. 
Table 6: Growth and Cyclicality of Debt Flows in Comparative Perspective

\begin{tabular}{|c|c|c|c|c|c|c|c|c|c|}
\hline & \multirow{2}{*}{ ADC } & \multicolumn{5}{|c|}{ Geographical Regions } & \multicolumn{3}{|c|}{ Income Groups } \\
\hline & & DA & ECA & LAC & MENA & SSA & UMIC & LMIC & LIC \\
\hline \multicolumn{10}{|c|}{ (a) Average and Median Annual Growths (Percent) } \\
\hline \multicolumn{10}{|l|}{ Means } \\
\hline$R D F$ & 40.88 & 35.97 & 67.95 & 170.00 & -8.23 & 42.35 & 178.85 & 37.91 & -64.20 \\
\hline$R L T D$ & -9.22 & 9.15 & 52.17 & 12.49 & -33.31 & 48.65 & 44.21 & -1.23 & 10.03 \\
\hline$R S T D$ & 75.03 & -8.36 & 415.78 & -20.29 & 257.10 & 6.61 & 56.43 & 115.26 & 2050.81 \\
\hline \multicolumn{10}{|c|}{ Medians } \\
\hline$R D F$ & 9.36 & 14.93 & 35.12 & -0.50 & -7.31 & 7.98 & 7.65 & 11.00 & -11.37 \\
\hline$R L T D$ & 7.17 & 7.75 & 22.09 & -2.28 & -15.79 & -5.41 & 7.38 & -6.67 & 5.77 \\
\hline$R S T D$ & 21.02 & 1.62 & 46.82 & 43.43 & 20.85 & 3.89 & 33.84 & 32.22 & 19.08 \\
\hline \multicolumn{10}{|c|}{ (b) Pairwise Correlations with Real GDP Growth } \\
\hline$R D F$ & $\begin{array}{r}0.01 \\
(0.94)\end{array}$ & $\begin{array}{r}0.34 \\
(0.04)\end{array}$ & $\begin{array}{l}-0.24 \\
(0.23)\end{array}$ & $\begin{array}{r}0.35 \\
(0.04)\end{array}$ & $\begin{array}{r}-0.07 \\
(0.68)\end{array}$ & $\begin{array}{r}0.25 \\
(0.15)\end{array}$ & $\begin{array}{r}-0.13 \\
(0.45)\end{array}$ & $\begin{array}{r}0.35 \\
(0.04)\end{array}$ & $\begin{array}{r}0.06 \\
(0.74)\end{array}$ \\
\hline$R L T D$ & $\begin{array}{r}0.10 \\
(0.56)\end{array}$ & $\begin{array}{r}0.19 \\
(0.26)\end{array}$ & $\begin{array}{c}-0.19 \\
(0.36)\end{array}$ & $\begin{array}{r}0.30 \\
(0.07)\end{array}$ & $\begin{array}{r}-0.04 \\
(0.83)\end{array}$ & $\begin{array}{r}0.26 \\
(0.12)\end{array}$ & $\begin{array}{r}0.26 \\
(0.12)\end{array}$ & $\begin{array}{r}0.37 \\
(0.03)\end{array}$ & $\begin{array}{r}0.05 \\
(0.78)\end{array}$ \\
\hline RSTD & $\begin{array}{r}0.12 \\
(0.49)\end{array}$ & $\begin{array}{r}0.32 \\
(0.06)\end{array}$ & $\begin{array}{r}-0.40 \\
(0.04)\end{array}$ & $\begin{array}{r}0.34 \\
(0.05)\end{array}$ & $\begin{array}{r}0.03 \\
(0.85)\end{array}$ & $\begin{array}{r}0.30 \\
(0.08)\end{array}$ & $\begin{array}{r}0.15 \\
(0.38)\end{array}$ & $\begin{array}{r}0.38 \\
(0.02)\end{array}$ & $\begin{array}{r}0.03 \\
(0.88)\end{array}$ \\
\hline
\end{tabular}

Sources: World Bank, World Development Indicators, Global Development Finance.

Notes: See notes to Table 2. 
Figure 10: Cost and Maturity Structure of External Borrowing in Developing Markets

(a) Income Groups

All Developing Countries
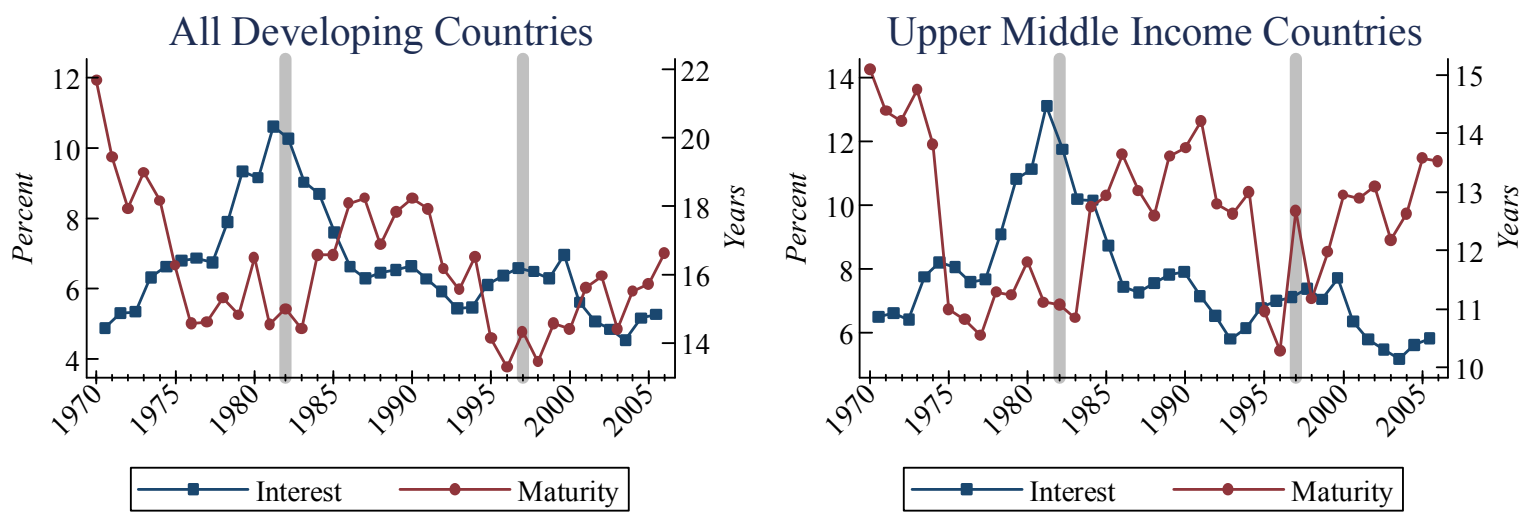

Lower Middle Income Countries

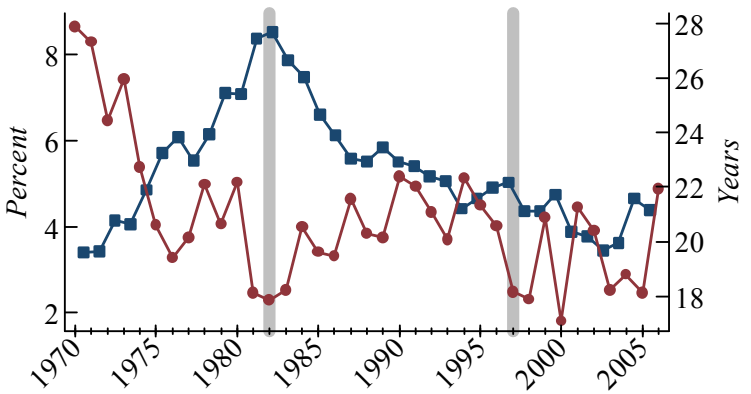

Low Income Countries

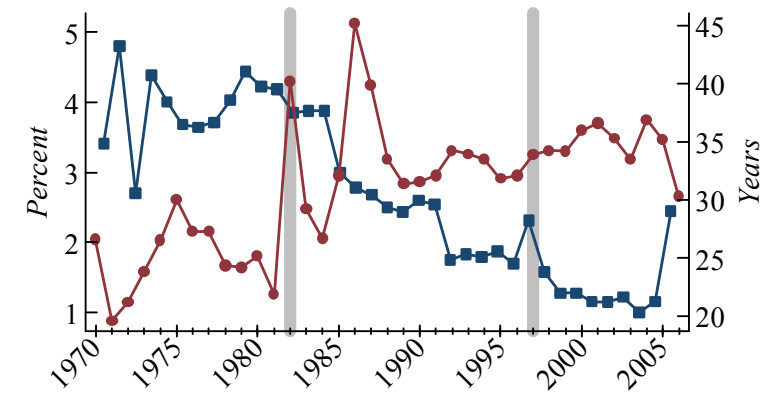

$\longrightarrow$ Interest $\longrightarrow$ Maturity

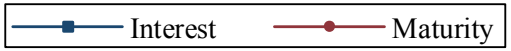

(b) Geographical Regions
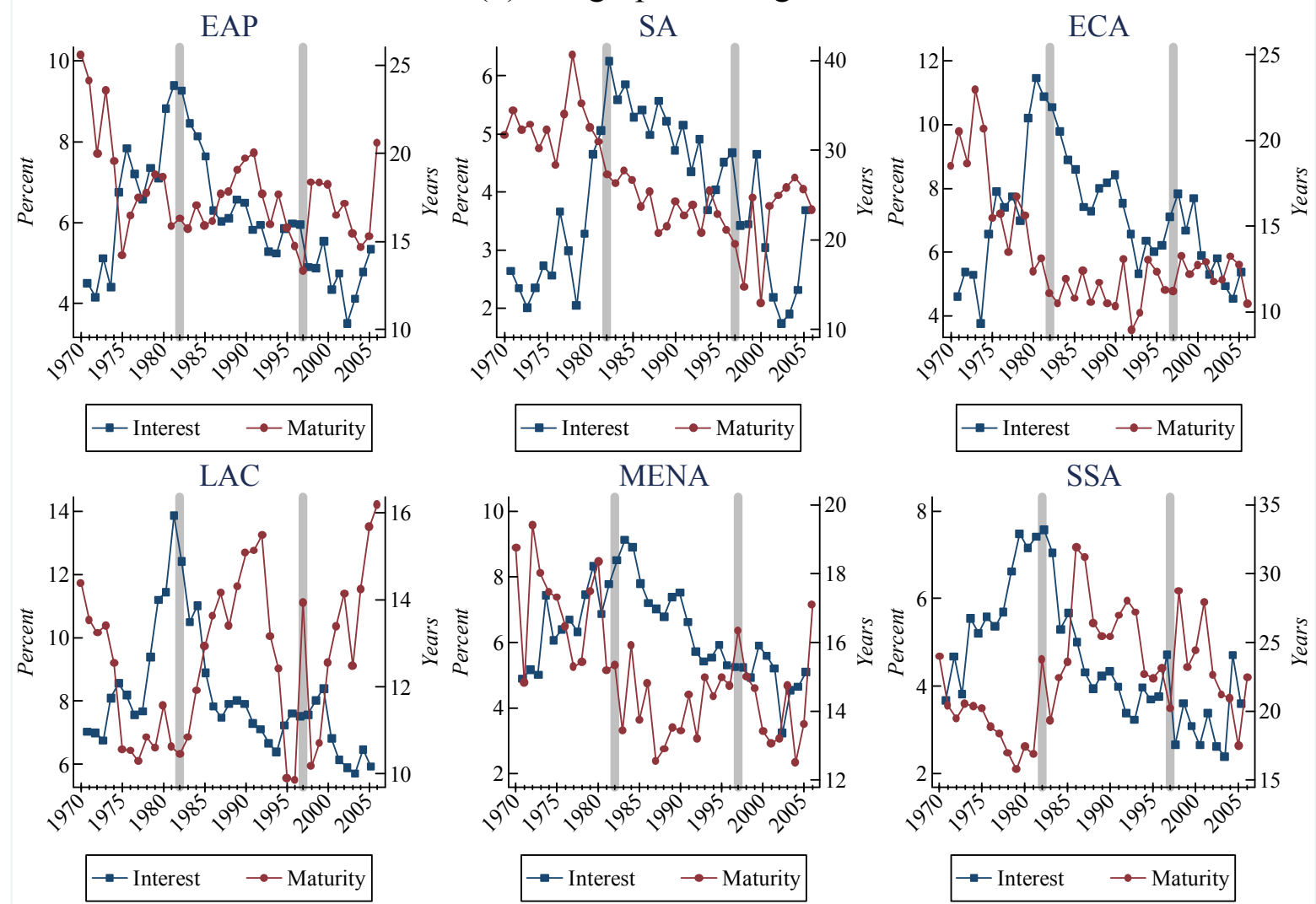

(continued on next page) 


\title{
(c) Spatial and Periodic Comparatives
}

\author{
(i) Country Groups
}

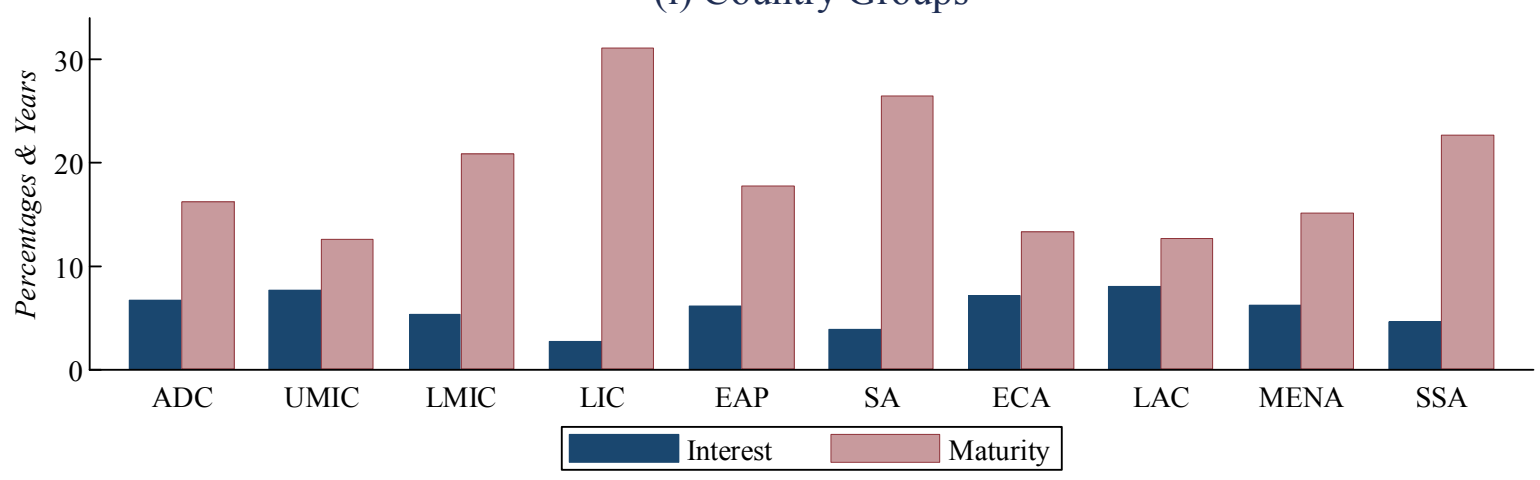

(ii) 5-Year Periods

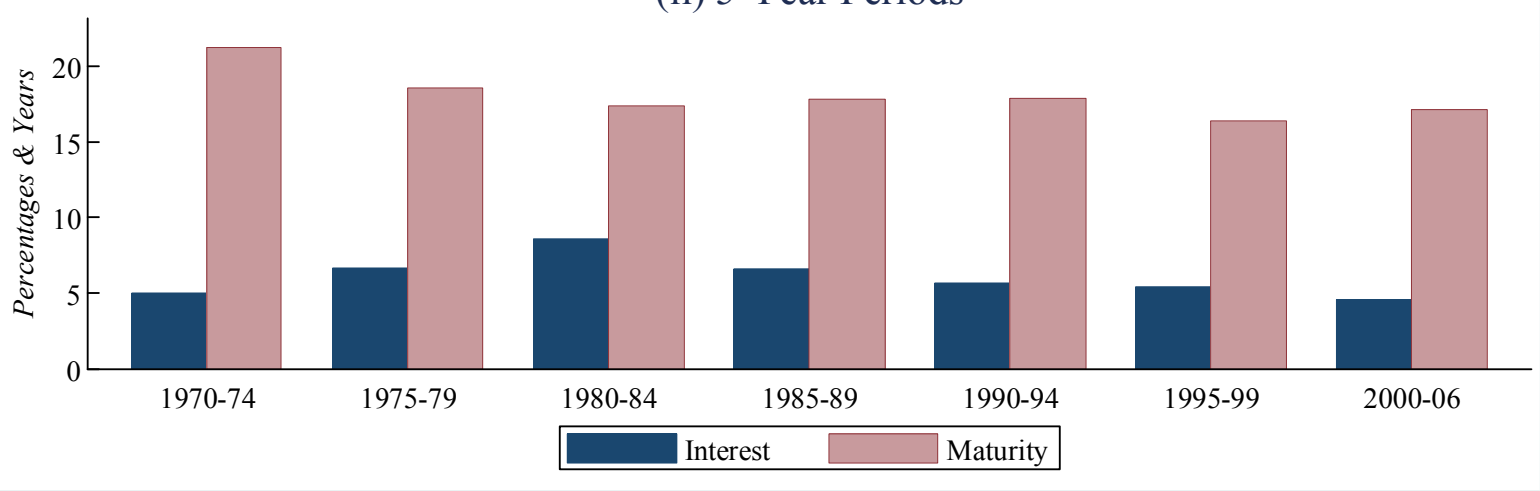

Sources: World Bank, Global Development Finance (GDF) and author's calculations.

Notes: Interest is the GDF's 'average interest on new external debt commitments' that represents the weighted average percentage interest rate on all new public and publicly guaranteed loans contracted during the year. To obtain the average, the interest rates for all public and publicly guaranteed loans are weighted by the amounts of the loans. Maturity refers to the GDF's 'average maturity on new external debt commitments' that is the weighted average number of years (i.e. the sum of grace and repayment periods) to original maturity dates of all new public and publicly guaranteed loans contracted during the year. Grace period for principal is the period from the date of signature of the loan or the issue of the financial instrument to the first repayment of principal. The repayment period is the period from the first to last repayment of principal. To obtain the average, the maturities of all public and publicly guaranteed loans are weighted by the amounts of the loans. Because I do not have access to all the loan data (amount, maturity and interest) that precludes me to follow my previous conventions, I use the regional data on interest rates and maturities exactly as given by the GDF. Hence, unlike before, all developing countries (ADC) here is the 'low and middle income countries' of the GDF and not composed of the individual sums of regional data. The geographical regions of East Asia and Pacific (EAP) and South Asia (SA) replace their conglomerate region of Developing Asia (DA) in this figure. In Panels (a) and (b), vertical lines mark 1982 Latin American and 1997 East Asian financial crises. See also notes to Figure 3. 


\section{References}

Aizenman J., Pinto, B. \& Radziwill, A., 2007. Sources for financing domestic capital: Is foreign saving a viable option for developing countries? Journal of International Money and Finance, 26, pp. 682-702.

Baxter, M. \& Jermann, U.J., 1997. The international diversification puzzle is worse than you think. The American Economic Review, 87(1), pp. 170-180.

Bekaert, G., Harvey, C.R. \& Lumsdaine, R.L., 2002. The dynamics of emerging market equity flows. Journal of International Money and Finance, 21(3), pp. 295-350.

Bosworth, B.P. \& Collins, S.M., 1999. Capital Flows to Developing Economies: Implications for Saving and Investment. Brookings Papers on Economic Activity, 1999(1), pp. 143-180.

Burnside, C., Eichenbaum, M. \& Rebelo, S., 2008. Currency crises models. In S. N. Durlauf \& L. E. Blume, eds. The New Palgrave Dictionary of Economics. Basingstoke: Nature Publishing Group, pp. 347-350.

Caramazza, F., Ricci, L. \& Salgado, R., 2004. International financial contagion in currency crises. Journal of International Money and Finance, 23(1), pp. 51-70.

Chan, K., Covrig, V. \& Ng, L., 2005. What determines the domestic bias and foreign bias? Evidence from mutual fund equity allocations worldwide. The Journal of Finance, 60(3), pp. 1495-1534.

Frankel, J. \& Wei, S.J., 2005. Managing macroeconomic crises: Policy lessons. In J. Aizenman \& B. Pinto, eds. Managing Economic Volatility and Crises. Cambridge: Cambridge University Press, pp. 315-405.

Fratzscher, M., 2003. On currency crises and contagion. International Journal of Finance \& Economics, 8(2), pp. 109-129.

Keskinsoy, B., 2017a. Lucas paradox in the long-run. Unpublished manuscript.

Keskinsoy, B., 2017b. Lucas paradox in the short-run. Unpublished manuscript.

Min, H-G. et al., 2003. Determinants of emerging-market bond spreads: Cross-country evidence. Global Finance Journal, 14(3), pp. 271-286. 
Obstfeld, M. \& Rogoff, K., 2000. The six major puzzles in international macroeconomics: Is there a common cause? NBER Macroeconomics Annual, 15, pp. 339-390.

Stulz, R.M., 1999. International portfolio flows and security markets. In M. Feldstein, eds. International Capital Flows. Chicago, IL: The University of Chicago Press, pp. 257-293.

Tesar, L.L., 1999. The role of equity in international capital flows. In M. Feldstein, eds. International Capital Flows. Chicago, IL: The University of Chicago Press, pp. 235-257.

Turner, P., 2002. Bond markets in emerging economies: An overview of policy issues. BIS Papers No 11.

World Bank, 2008. Global Development Finance: The Role of International Banking. Washington, DC: The World Bank.

World Bank, 2012. Global Development Finance: External Debt of Developing Countries. Washington, DC: The World Bank. 